Article

\title{
Sweet Immunity: Inulin Boosts Resistance of Lettuce (Lactuca sativa) against Grey Mold (Botrytis cinerea) in an Ethylene-Dependent Manner
}

\author{
Lukasz Paweł Tarkowski ${ }^{1}$, Bram Van de Poel ${ }^{2}$ (D), Monica Höfte ${ }^{3}$ and Wim Van den Ende ${ }^{1, *(D)}$ \\ 1 Laboratory of Molecular Plant Biology, KU Leuven, Kasteelpark Arenberg 31, 3001 Leuven, Belgium; \\ lukaszpawel.tarkowski@kuleuven.be \\ 2 Laboratory of Molecular Plant Hormone Physiology, Division of Crop Biotechnics, Department of \\ Biosystems, KU Leuven, 3001 Leuven, Belgium; bram.vandepoel@kuleuven.be \\ 3 Laboratory of Phytopathology, Department of Plants and Crops, UGhent, 9000 Ghent, Belgium; \\ monica.hofte@ugent.be \\ * Correspondence: wim.vandenende@kuleuven.be; Tel.: +32-1632-1952
}

Received: 12 January 2019; Accepted: 22 February 2019; Published: 28 February 2019

\begin{abstract}
The concept of "Sweet Immunity" postulates that sugar metabolism and signaling influence plant immune networks. In this study, we tested the potential of commercially available inulin-type fructans to limit disease symptoms caused by Botrytis cinerea in lettuce. Spraying mature lettuce leaves, with inulin-type fructans derived from burdock or chicory was as effective in reducing grey mold disease symptoms caused by Botrytis cinerea as spraying with oligogalacturonides (OGs). OGs are well-known defense elicitors in several plant species. Spraying with inulin and OGs induced accumulation of hydrogen peroxide and levels further increased upon pathogen infection. Inulin and OGs were no longer able to limit Botrytis infection when plants were treated with the ethylene signaling inhibitor 1-methylcyclopropene (1-MCP), indicating that a functional ethylene signaling pathway is needed for the enhanced defense response. Soluble sugars accumulated in leaves primed with OGs, while 1-MCP treatment had an overall negative effect on the sucrose pool. Accumulation of $\gamma$-aminobutyric acid (GABA), a stress-associated non-proteinogenic amino acid and possible signaling compound, was observed in inulin-treated samples after infection and negatively affected by the 1-MCP treatment. We have demonstrated for the first time that commercially available inulin-type fructans and OGs can improve the defensive capacity of lettuce, an economically important species. We discuss our results in the context of a possible recognition of fructans as Damage or Microbe Associated Molecular Patterns.
\end{abstract}

Keywords: sweet immunity; Botrytis cinerea; fructan; oligogalacturonides; lettuce; ethylene; 1-MCP; GABA

\section{Introduction}

In a rapidly changing world, there is a need for high yielding, stress tolerant crops. Pest attacks account for an estimated loss of $\$ 20-40$ billion worldwide [1]. Besides classical breeding efforts, the use of chemical pesticides is widespread, although toxicity risks for human health and the environment are an issue [2], and production costs are growing exponentially [3]. Sustainable alternatives could lie in "biological control" strategies [4] such as the use of beneficial microorganisms [5] or 'priming' plants by spraying natural compounds [6]. Priming helps the plant to react faster and/or more strongly to a future pathogen attack, and is believed to work with minimal energy inputs, triggering crop resistance to (a)biotic stresses without major implications for plant fitness [7]. Priming can be useful in the field and greenhouse context on intact plants, but also for postharvest application on fruits [8] and detached 
leaves [9]. In this context, it is important to note that inulin is a safe product for human consumption, also possessing prebiotic properties [10].

In primed plants, plant immune signaling pathways are activated after pathogen infection, involving all the major defense phytohormones: jasmonic acid (JA), salicylic acid (SA), abscisic acid (ABA), and ethylene in a pathosystem-specific manner [11-13]. In general, it is accepted that ethylene, JA, and ABA play a major role in modulating defense responses against necrotrophs $[14,15]$, whereas SA is known to be critical for defense against biotrophs $[16,17]$. However, exceptions to this dichotomy are observed $[18,19]$. The role of ethylene may also depend on the physiological status of the plant, the plant species and the exact status of the sampled materials $[20,21]$. The chemical nature of the priming compounds characterized so far is very heterogeneous, including amino acids, organic acids, inorganic molecules, and other categories [22-24]. Among those, carbohydrates recently gained considerable attention $[25,26]$ because of related advantages such as low production costs and absence of toxicity. Carbohydrates are the products of photosynthesis, and besides their fundamental metabolic role, the signaling properties of molecules such as hexoses and sucrose (Suc) are well-established [27,28]. Soluble sugar signaling and dynamics are crucial for the control of plant development and organogenesis [29-31], as well as for coping with biotic and abiotic stresses [32-34]. Their emerging importance in immune processes lead to the development of the "Sweet Immunity" concept, which postulates that sugars and components of the sugar metabolism are essential players in plant defense strategies [35]. Attempts to use soluble carbohydrates such as cell wall-derived oligogalacturonides (OGs) [36] and cellobiose [37] as priming agents led to important successes. However, few research efforts focused on priming or treatments with non-structural soluble sugars [25,38].

Soluble sugar levels are tightly controlled by transporters and enzymes. Among them, invertases are able to irreversibly split Suc into glucose (Glc) and fructose (Fru) and play a central role in source-sink partitioning and plant development $[39,40]$. These enzymes are important players in the plant adaptation strategies towards biotic and abiotic stresses [41-43], and can be classified in acidic and alkaline forms [44].

Here, we focus on fructans, which accumulate in approximately $15 \%$ of land plants. These oligo- and polysaccharides are synthesized by elongating the Fru part of Suc with Fru moieties via $\beta(2-1)$ and/or $\beta(2-6)$ linkages, resulting in three major subclasses: inulins ( $\beta(2-1)$ bonds), levans $(\beta(2-6)$ bonds), and graminans (mixed bonds) [45]. Fructans can also be synthesized by adding a Fru moiety to the $\mathrm{C} 6$ of the Glc residue of Suc through a $\beta(2-6)$ bond. This results in the synthesis of neokestose, the starting brick for the build-up of neofructan series. Neofructans can be further divided into neoinulins, neolevans, and agavins [46] (Figure 1). Besides their role as reserve compounds, fructans are recognized players in plant adaptation responses to abiotic stress [47-49]. Their contribution to physiological adjustments during drought $[50,51]$ and cold stress $[52,53]$ is well described, involving mechanisms such as osmotic protection of cellular components. Besides their relevance in abiotic stress adaptation, an emerging role for fructans under biotic challenges has been proposed [54,55]. Fructan accumulation in vivo was linked to pathogen resistance in plant species such as agave and wheat $[54,56]$ and exogenous application of inulins extracted from burdock (Arctium lappa) roots (burdock fructooligosaccharides (BFOs)) proved to be effective in boosting plant resistance towards biotic attacks in pathosystems such as Nicotiana tabacum-tobacco mosaic virus and Cucumis sativus-Colletotrichium orbiculare $[57,58]$. Thus, the use of fructans as priming agents in the biocontrol context represents an attractive possibility. The goal of this study was to test the potential of inulin fructans to induce resistance in the leafy vegetable lettuce (Lactuca sativa) against the model necrotrophic fungus Botrytis cinerea, able to infect more than 200 plant species [59], and to study the underlying mechanisms. 


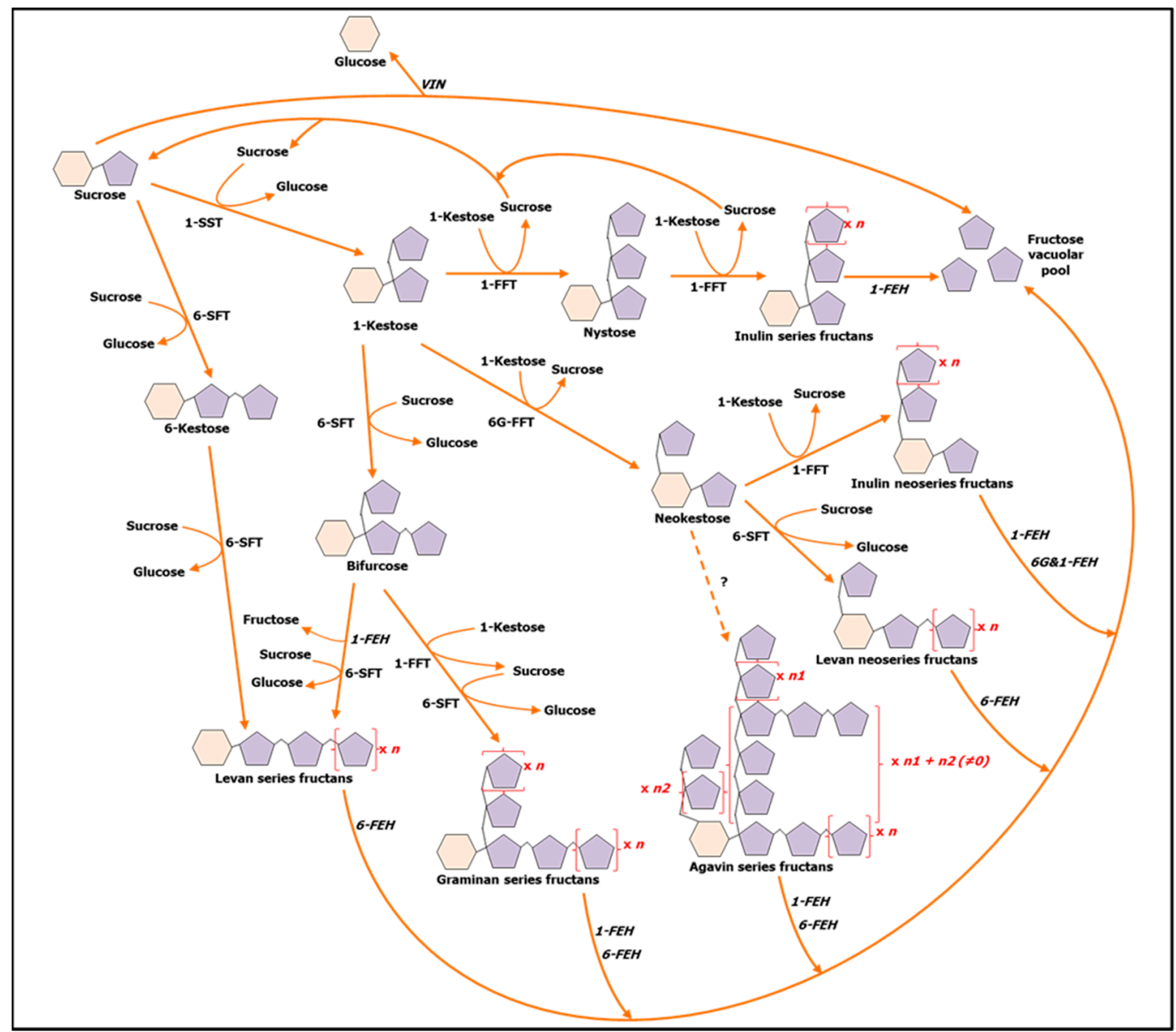

Figure 1. Schematic representation of fructan metabolism in plants. FEH = Fructan Exohydrolase; FFT $=$ Fructan:Fructan Fructosyltransferase; SFT = Sucrose:Fructan Fructosyltransferase; SST = Sucrose:Sucrose Fructosyltransferase; VIN = Vacuolar Invertase. 1- and 6- prefixes of enzymes refer to the position of the $C$ of the Fru moiety that is attacked by the enzyme. The 6G- prefix indicates that the enzyme acts on the $\mathrm{C} 6$ of the Glc moiety. All the described reactions take place in the vacuole $[45,46]$. The biosynthetic pathway of agavins are still under investigation. Although fructans are believed to be stored in the vacuole, their presence in the apoplast suggested a possible vesicular-mediated transport between the vacuole and the apoplast [47].

\section{Results}

\subsection{Burdock Inulin Is Effective in Protecting Lettuce Leaves against Botrytis}

First, the immunostimulatory activity of BFOs was tested in our pathosystem, composed of lettuce (Lactuca sativa var. Gisela) and Botrytis cinerea strain B05.10 [60]. The same concentration reported from the previous papers $\left(5 \mathrm{~g} \cdot \mathrm{L}^{-1}\right)$ was used to spray 45 day-old lettuce plants and inoculate them 3 days after priming with Botrytis. To confirm that the observed effect is not associated with impurities (small soluble sugars Glc, Fru, and Suc and the smallest DP (degree of polymerization) 3-6 inulin type fructans), present in our fructan formulation, BFOs priming was compared with the subsequent controls: fully hydrolyzed BFOs (H BFOs), BFOs dialyzed with a $1 \mathrm{kDa}$-cutoff membrane (which allows exchange of fructan oligosaccharides up to $\mathrm{DP}=6)(\mathrm{D}$ BFOs), hydrolyzed and dialyzed BFOs (HD BFOs). As a positive control, oligogalacturonides (OGs) was selected, which is a well-characterized DAMPs (Damage-Associated Molecular Patterns) [36] at a concentration of $0.5 \mathrm{~g} \cdot \mathrm{L}^{-1}$. Conductivity tests estimated the molarity of a $5 \mathrm{~g} \cdot \mathrm{L}^{-1}$ BFOs solution between 50 and $55 \mathrm{mM}$. Thus, to take possible osmotic effects into account, sorbitol $50 \mathrm{mM}$ was used as osmotic control. After priming, fully-grown sprayed leaves were detached and inoculated. Figure 2 shows a significant decrease in disease 
symptoms in leaves treated with BFOs, D BFOs, and OGs (Figure 2A,B). These data confirm the priming efficacy of BFOs in our pathosystem, excluding any artifacts due to osmotic or Fru-dependent effects. Furthermore, application of pure DP $>6$ BFOs resulted in an efficient priming, demonstrating that the protective effect could not be attributed to small soluble sugar impurities. In addition, we proved for the first time that OGs are effective defense elicitors on lettuce plants. It was also tested whether exogenous application of the common soluble sugars Suc, Glc, and Fru at $50 \mathrm{mM}$ had an effect on the defense response against Botrytis, but no positive results were found (Figure S1).

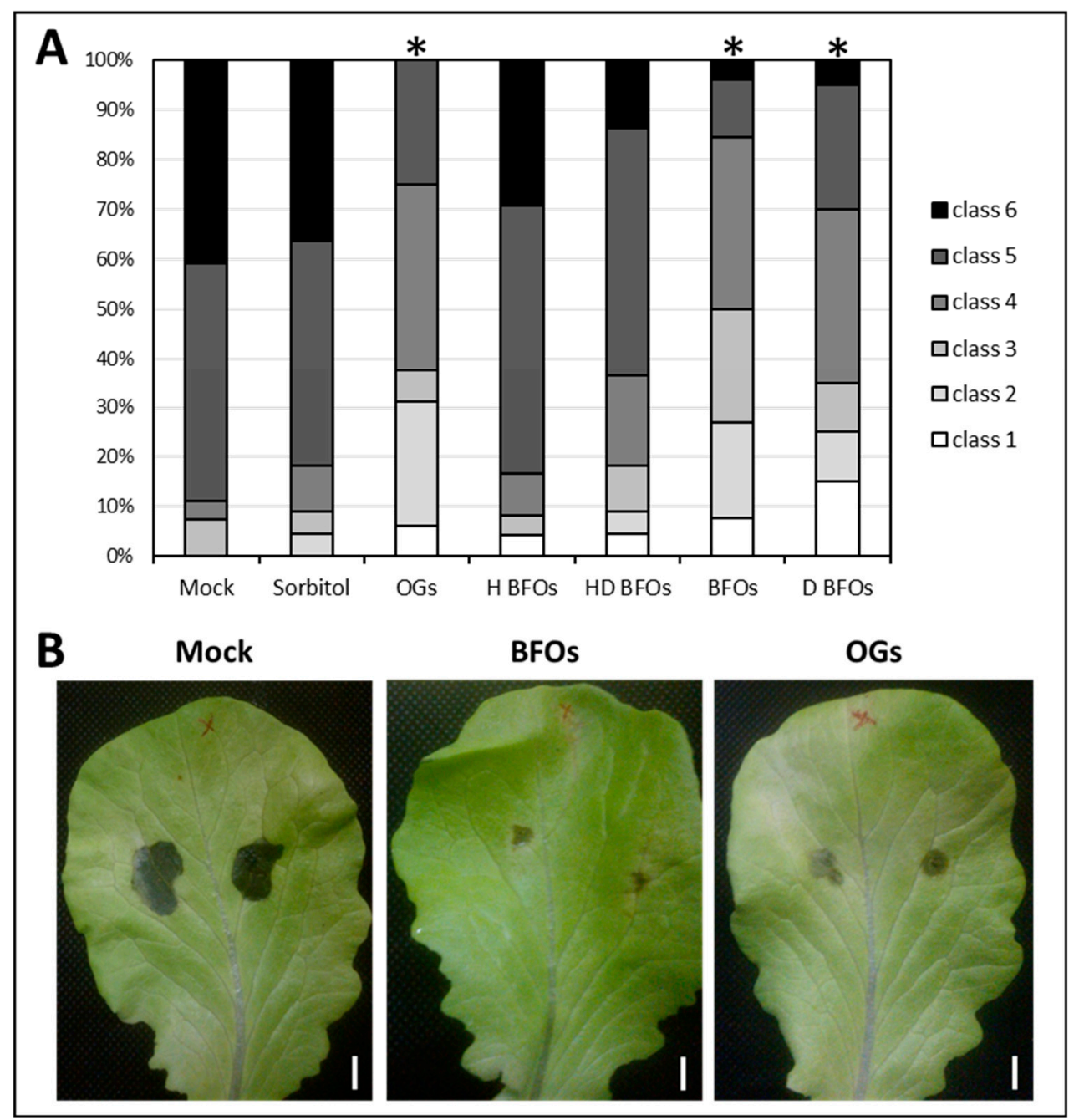

Figure 2. (A) Stacked-column chart illustrating severity class distribution resulting from the burdock fructooligosaccharides (BFOs) specificity test. Asterisks indicate significance against mock (water) at $p<0.01$ according to non-parametrical, two-tailed, Mann-Whitney $u$-test, $n \geq 16$. This experiment was repeated three times with consistent results; (B) Representative pictures of Botrytis lesions on lettuce leaves treated with water (mock), BFOs $5 \mathrm{~g} \cdot \mathrm{L}^{-1}$ and oligogalacturonides (OGs) $0.5 \mathrm{~g} \cdot \mathrm{L}^{-1}$ at 4 DPI (days post inoculation). Bars $=1 \mathrm{~cm}$.

\subsection{Chicory-Derived Inulin Is Effective in Inducing Protection in the Lettuce-Botrytis cinerea Pathosystem}

To understand whether the immunostimulatory effect of BFOs is source-specific or shared by inulin-type fructans extracted from other sources, BFOs priming efficiency of commercially available inulin (Sigma) derived from chicory (Cichorium intybus) at similar concentrations. Figure 3A compares the sugar profiles of BFOs extracted from burdock and commercial inulin derived from chicory. Disease scoring results revealed that commercial chicory-derived inulin priming was still efficient in significantly decreasing the disease symptoms in our pathosystem (Figure 3B). These data confirm 
that inulin-type fructans are effective priming agents in this pathosystem regardless of their origin. Decreasing the inulin concentration from 5 to $1 \mathrm{~g} \cdot \mathrm{L}^{-1}$ still led to significantly decreased disease symptoms (Figure 3C). Comparing the 1 and $5 \mathrm{~g} \cdot \mathrm{L}^{-1}$ treatments, no obvious differences were observed in disease symptoms. Botrytis growth on PDA plates supplemented with different inulin concentrations was tested as well, without finding differences between the treatments (Figure S2). This result suggests that the inulin effect is plant-mediated. For subsequent experiments, chicory inulin at $1 \mathrm{~g} \cdot \mathrm{L}^{-1}$ was used.

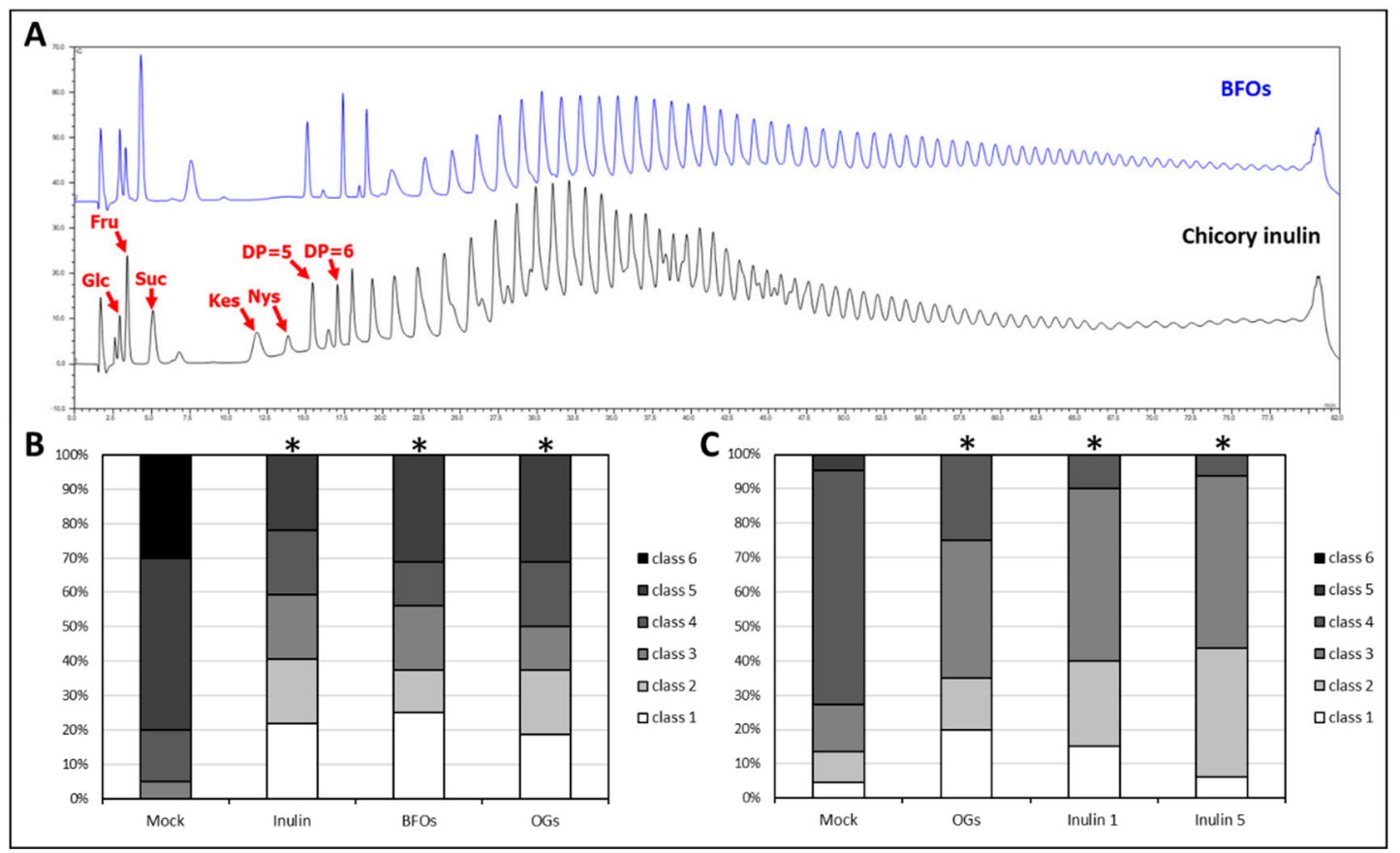

Figure 3. (A) Comparison between chromatograms resulting from injection of BFOs and chicory inulin (HPAEC-IPAD). $Y$ axis = detector response in nanoCoulomb; $X$ axis = elution time in min; Glc = glucose; Fru = fructose; Suc = sucrose; Kes = 1-kestose; Nys = nystose; $(\mathbf{B})$ Results of the disease scoring experiment comparing BFOs and chicory inulin priming efficiency. Asterisks indicate significance against mock (water) at $p<0.01$ according to non-parametrical, two-tailed, Mann-Whitney $u$-test. This experiment was repeated three times with consistent results; (C) Results of the disease scoring experiment comparing chicory inulin at $1 \mathrm{~g} \cdot \mathrm{L}^{-1}$ (inulin 1 ) and the same solution at $5 \mathrm{~g} \cdot \mathrm{L}^{-1}$ (inulin 5) priming efficiency. Asterisks indicate significance against mock at $p<0.01$ according to Mann-Whitney $u$-test. This experiment was repeated three times with consistent results.

\subsection{Inulin Treatment Induces $\mathrm{H}_{2} \mathrm{O}_{2}$ Accumulation}

Histochemical measurements of $\mathrm{H}_{2} \mathrm{O}_{2}$ accumulation were performed in primed and infected leaves using the DAB (3,3'-diaminobenzidine) assay [61]. Leaves were sampled $3 \mathrm{~h}$ post priming ( $3 \mathrm{hPP}), 1$ day post priming (1 DPP), 0 days post inoculation (or 3 days post priming) (0 DPI), and 1 day post inoculation (1 DPI). To discriminate between leaf detachment and inoculation effects, an additional control without Botrytis inoculation (uninfected) was sampled 1 DPI. Results are shown in Figure 4 and more representative pictures are shown in Figure S3. Already $3 \mathrm{~h}$ after spraying OGs and inulin, a significant $\mathrm{H}_{2} \mathrm{O}_{2}$ accumulation was detected and this trend was maintained at 1 DPP, indicating a steady production of $\mathrm{H}_{2} \mathrm{O}_{2}$ over the first $24 \mathrm{~h}$. At $3 \mathrm{DPP}, \mathrm{H}_{2} \mathrm{O}_{2}$ levels in inulin samples decreased compared to the mock treatment, whereas $\mathrm{H}_{2} \mathrm{O}_{2}$ levels of OGs samples remained steady (Figure 4A). After infection, a drastic increase in $\mathrm{H}_{2} \mathrm{O}_{2}$ levels was visible in both OGs and inulin-treated leaves. An increase in $\mathrm{H}_{2} \mathrm{O}_{2}$ content in the mock sample was also observed compared to the time-point before inoculation, however this effect was likely due to leaf detachment, because a similar $\mathrm{H}_{2} \mathrm{O}_{2}$ level was detected in the uninfected control (Figure 4A). 


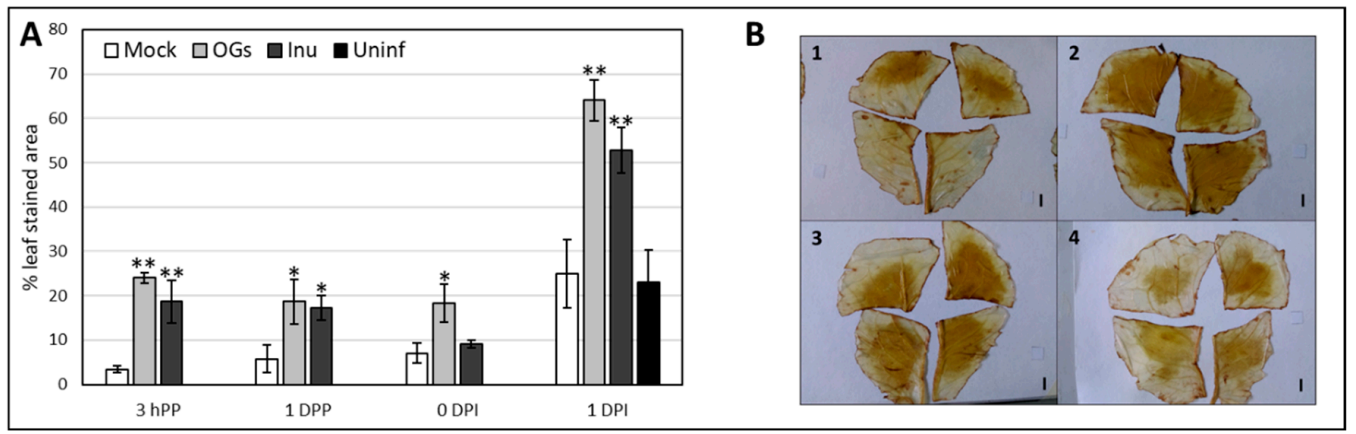

Figure 4. Induction of $\mathrm{H}_{2} \mathrm{O}_{2}$ accumulation by OGs and inulin priming. Mock = water-primed leaves; OGs = OGs-primed leaves; Inu = chicory inulin-primed leaves; Uninf = water-primed leaves inoculated with a mock solution ( $1 / 2$ strength Potato dextrose broth). (A) The bar charts illustrate the percentage of DAB (3,3'-diaminobenzidine) stained leaf area in mock-treated and primed leaves at different time-points. $3 \mathrm{hPP}=3 \mathrm{~h}$ post priming; $1 \mathrm{DPP}=1$ day post priming; $0 \mathrm{DPI}=0$ days post inoculation; $1 \mathrm{DPI}=1$ day post inoculation. Asterisks indicate statistically significant differences between treatments and mock for each time-point $\left({ }^{*} p<0.05,{ }^{* *} p<0.01\right)$ according to Students $t$-test. The experiment was repeated twice with consistent results; (B) Representative pictures of DAB-stained leaves collected at 1 DPI. (1) Mock (2) OGs (3) Inulin (4) Uninfected. Scale bars $=1 \mathrm{~cm}$.

\subsection{Inulin-Enhanced Plant Defense Requires Ethylene Signaling}

Since in lettuce, ethylene signaling was shown to be activated in response to Botrytis infection [60], we hypothesized that ethylene signaling could be involved in basal and elicitor-induced protection to Botrytis in lettuce. To test this, we treated mock, OGs, and inulin-primed plants with $10 \mathrm{ppm} 1-\mathrm{MCP}$ (1-methylcyclopropene), a competitive inhibitor of ethylene signaling [62], for $24 \mathrm{~h}$ before inoculation and compared disease scoring results with the ones from untreated plants. Results revealed that both inulin and OGs were no longer able to decrease disease symptoms after a 1-MCP treatment (Figure 5B), indicating that a functional ethylene signaling pathway is required to enhance the defense response after priming with these compounds. Interestingly, no statistical difference was detected by comparing mock treatments with and without 1-MCP application ( $p=0.904$, Mann-Whitney $u$-test), suggesting that ethylene signaling is not required for basal resistance in mature lettuce leaves against Botrytis. To test whether 1-MCP application may have a direct effect on Botrytis growth and sporulation, we fumigated PDA plates inoculated with Botrytis with $10 \mathrm{ppm} 1-\mathrm{MCP}$ and looked for differences in mycelial growth compared to untreated plates after 7 and 12 days. No differences were detected at either time-point tested (Figure 5C), indicating that 1-MCP does not affect Botrytis growth on the plate. We tried the same experiment using $10 \mu \mathrm{M}$ AVG (2-aminoethoxyvinyl glycine), an ethylene biosynthesis inhibitor which blocks synthesis of 1-aminocyclopropane-1-carboxylic acid (ACC) [63]. We obtained a similar reduction of OGs and inulin-triggered protection, although results were less pronounced when compared to 1-MCP data (Figure S4). This suggests that ethylene synthesis plays a role in inulin and OGs-induced protection but is not required for basal resistance in mature lettuce leaves against Botrytis.

2.5. Oligogalacturonides (OGs) Treatment and 1-Methylcyclopropene (1-MCP) Application Induce Changes in Soluble Sugar Content, and Have a Major Impact on Suc Accumulation

Fru, Glc, and Suc content of leaf samples collected immediately before inoculation (0 DPI or 3 DPP) and 1 day post inoculation (1 DPI) were analyzed. To properly take into account the effect of priming, samples taken immediately before the priming event (0 days post priming, 0 DPP) were also collected. To distinguish between detachment and pathogen effects, uninfected control leaves were sampled at 1 DPI. Results are summarized in Figure 6, showing that Suc levels increased after OGs priming (Figure 6A). Interestingly, during infection a significant decrease in Suc content was registered for the same treatment (Figure 6B). Regarding the 1-MCP effect on Suc levels, a significant drop in all 
the treatments was detected before and after inoculation, with the only exception of OGs samples at 1 DPI (Figure 6B). These data suggest a strong negative effect of 1-MCP on Suc accumulation. Similar to Suc, Glc levels were positively affected by OGs priming, and the 1-MCP application lowered Glc levels in all treatments, although not significantly in inulin samples (Figure 6C). Higher Glc levels were registered in uninfected samples as compared to infected samples, suggesting an increase in Glc use in the presence of the pathogen. However, we do not know whether this observation can be ascribed to direct nutrient utilization from the host or is due to the pathogen. 1-MCP negatively affected only inulin samples at this time-point (Figure 6D). Regarding Fru levels, again a positive effect of OGs priming was observed, while the 1-MCP treatment had no significant effect at this stage (Figure 6E). A strong increase in Fru levels was detected in all infected samples, including the uninfected control, which might suggest that detachment induces Fru accumulation in lettuce leaves (Figure 6F). As for Glc, 1-MCP treatments significantly decreased Fru levels only for inulin samples (Figure 6F). Our data indicate an overall negative effect of 1-MCP on the Suc pool, a minor effect on the hexose pool, and a particularly drastic effect on inulin-primed samples. Regarding priming treatments, OGs stimulate an accumulation of soluble sugars after priming.

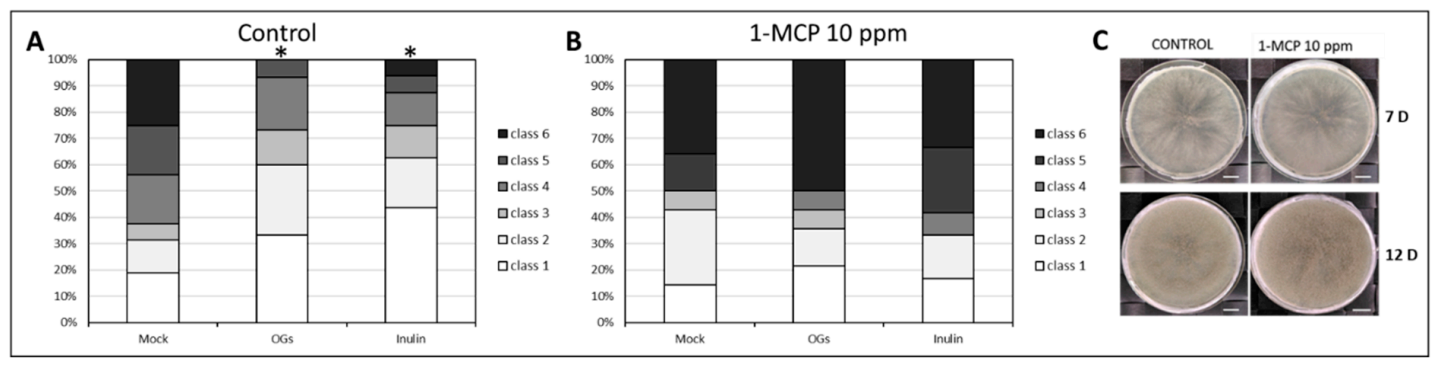

Figure 5. Effect of 1-methylcyclopropene (1-MCP) treatment on basal and OGs- and inulin-induced protection against Botrytis cinerea. (A) Disease scoring results of primed leaves not treated with 1-MCP; (B) Disease scoring results of primed leaves treated for $24 \mathrm{~h}$ with $10 \mathrm{ppm}$ 1-MCP before pathogen inoculation. Asterisks indicate significance against mock $(p<0.05$, Mann-Whitney $u$-test). This experiment was repeated three times with consistent results; (C) Representative pictures of Botrytis cinerea growth assay on PDA plates after a treatment with $10 \mathrm{ppm} 1-\mathrm{MCP}$, with pictures taken 7 days (7 D) and 12 days (12 D) after plate inoculation. Bars $=1 \mathrm{~cm}$.

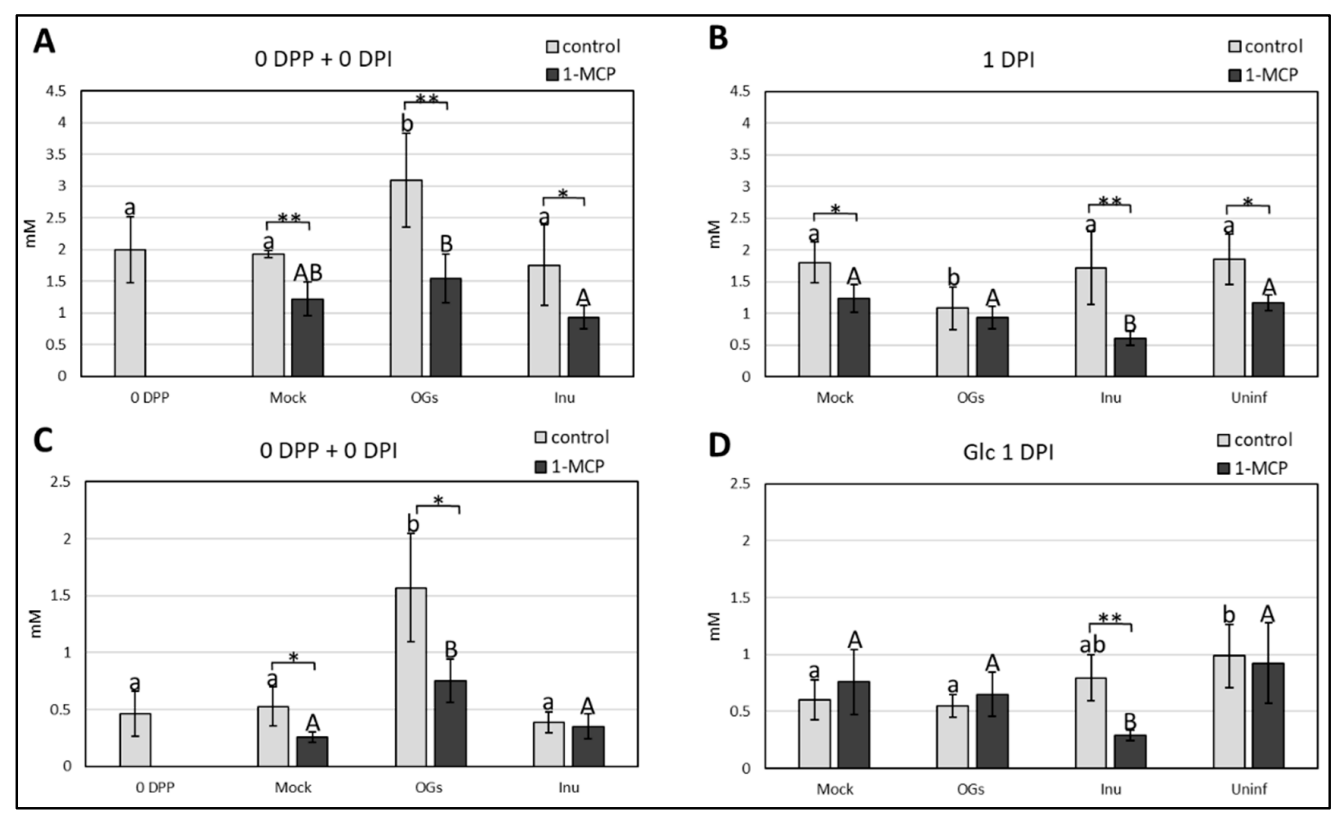

Figure 6. Cont. 


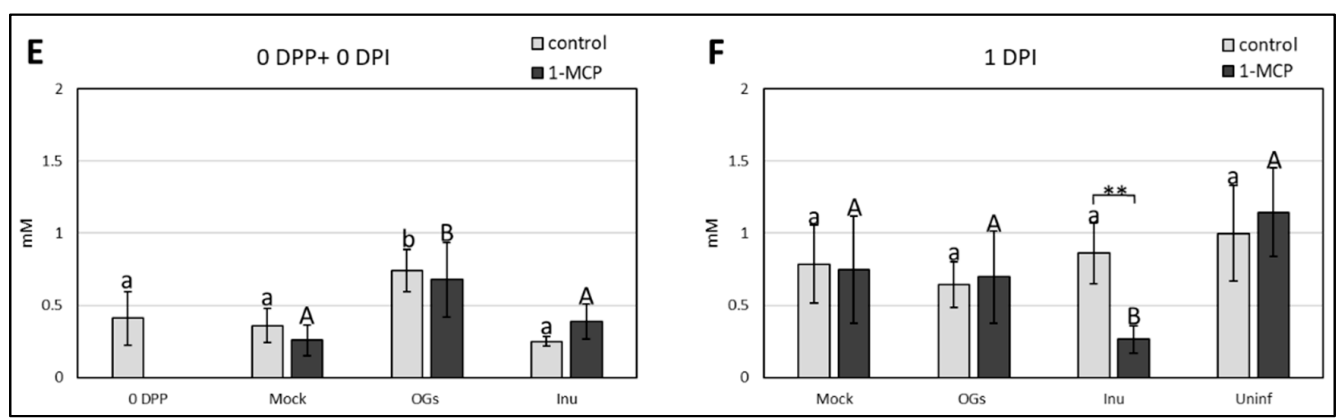

Figure 6. Soluble sugar analysis from leaf samples collected from the 1-MCP experiment. Mock = water-primed leaves; OGs = OGs-primed leaves; Inu = chicory inulin-primed leaves; Uninf = Water-primed leaves inoculated with a mock solution (1/2 strength Potato dextrose broth). (A) Suc quantification at $0 \mathrm{DPP}$ (before priming $=0 \mathrm{DPP}$ ) and 0 DPI (3 days after priming and before inoculation); (B) Suc quantification at 1 DPI; (C) Glc quantification at 0 DPP and 0 DPI; (D) Glc quantification at 1 DPI; (E) Fru quantification at 0 DPP and 0 DPI; (F) Fru quantification at 1 DPI. Bars marked with same letter(s) are not significant between each other, bars that have no letters in common indicate significance between treatments ( $p<0.05$, one-way ANOVA (analysis of variance) followed by Tukey's post-hoc test). Lowercase letters refer to comparison between control treatments, capital letters refer to comparison between 1-MCP treatments. Asterisks indicate significance between control and 1-MCP conditions referring to the same priming treatment $\left({ }^{*} p<0.05,{ }^{* *} p<0.01\right.$, Student's $t$-test). Values represent the average \pm standard deviation of five biological replicates.

\subsection{Effect of Priming and 1-MCP on Acidic Invertase Activities}

Total activity of soluble (VI, Vacuolar Invertase) and insoluble (CWI, Cell Wall Invertase) acidic invertases was measured in our samples in order to assess their involvement in priming and response to Botrytis. Results collected for CWI activity show that priming treatments had no effect on activity levels of invertases, but their activity was enhanced by the 1-MCP treatment in all samples, although with a smaller magnitude in the case of CWI after inulin priming (Figure 7A). At 1 DPI, the 1-MCP effect appears to become even stronger, independently from the priming treatment considered. No differences between control priming treatments (mock, OGs, inulin) were observed (Figure 7B). Importantly, activity levels of CWI in uninfected samples raised when compared to all the other infected samples (Figure 7B). This suggests that pathogen perception at this early stage triggers a decrease in CWI activity, contrary to what was expected. VI activities at 0 DPI followed substantially the same trend of the corresponding CWI data, with a strong increase in activity after the 1-MCP treatment for all priming agents compared to the control treatment. In contradiction to CWI activity, this increase in VI activity was more prominent in the inulin-treated samples (Figure 7C). At 1 DPI, VI activity increased in mock samples to a similar extent to what was observed for CWI (Figure 7D). A significant decrease in VI activity was noticed in inulin and uninfected samples when compared to the mock. Interestingly, the 1-MCP application resulted in a completely opposite outcome of VI activity with respect to the CWI 1 DPI data: where 1-MCP stimulates CWI activity 1 DPI, it does not do so for VI for the mock, OGs and inulin primed samples. However, a slight increase of VI activity of the uninfected samples treated with 1-MCP was recorded (Figure 7D). Our data suggests that ethylene signaling has a negative effect on both CWI and VI post priming, but during infection this repression is lost for VI but not for CWI. 


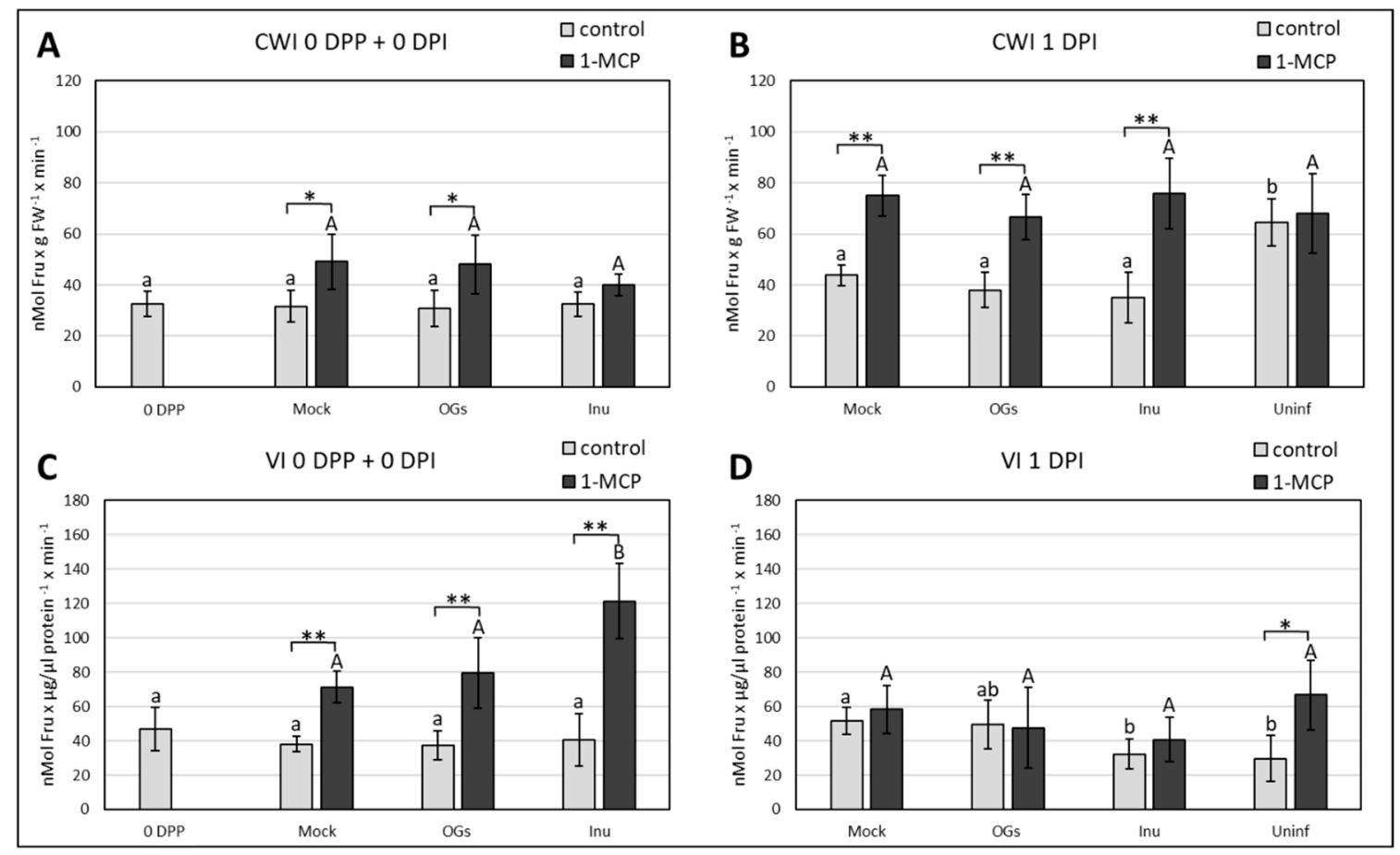

Figure 7. Acidic invertase activities in primed and 1-MCP treated samples. Mock = water-primed leaves; OGs = OGs-primed leaves; Inu = chicory inulin-primed leaves; Uninf = water-primed leaves inoculated with a mock solution (1/2 strength Potato dextrose broth). (A) CWI (Cell Wall Invertase) activities at 0 DPP and 0 DPI; (B) CWI activities at 1 DPI; (C) VI (Vacuolar Invertase) activities at 0 DPP and 0 DPI; (D) VI activities at 1 DPI. Bars marked with same letter(s) are not significant between each other, bars that have no letters in common indicate significance between treatments ( $p<0.05$, one-way ANOVA followed by Tukey's post hoc test). Lowercase letters refer to comparison between control treatments, capital letters refer to comparison between 1-MCP treatments. Asterisks indicate significance between control and 1-MCP conditions referring to the same priming treatment $\left({ }^{*} p<0.05,{ }^{* *} p<0.01\right.$, Student's $t$-test). Values represent the average \pm standard deviation of five biological replicates.

\section{7. $\gamma$-Aminobutyric Acid (GABA) Accumulates in Inulin-Primed Leaves after Botrytis Infection}

$\gamma$-Aminobutyric acid (GABA) levels in leaf samples from the previous 1-MCP experiment were quantified. Results obtained at 0 DPI did not show differences between priming treatments for both the 1-MCP treated and untreated leaves, although a decreasing trend following 1-MCP treatment can be recognized in this respect (Figure 8A). Data collected at 1 DPI showed an increase in GABA levels for inulin-treated samples (Figure 8B). Interestingly, 1-MCP only had a negative effect on GABA content in the OG and inulin primed leaves (Figure 8B). These results suggest that ethylene signaling is required to induce GABA accumulation after priming and during subsequent infection. Proline (Pro) levels in our samples were assessed as well, and results at 0 DPI indicated no significant differences between priming treatments or the 1-MCP application (Figure 8C). At 1 DPI, a significant increase in mock-primed samples was observed when compared to uninfected control, indicating that Botrytis infection triggered Pro accumulation (Figure 8D). 1-MCP treatment did not result in significant differences in Pro accumulation compared to control treatments, although lowered Pro values in OGs and inulin primed samples were detected. Furthermore, 1-MCP treated mock samples had significantly higher Pro levels compared to OGs, inulin and uninfected samples treated with 1-MCP (Figure 8D). These results suggest a stimulation of Pro production during infection. There does not seem to be a clear effect of priming on Pro levels before and after infection. The role of 1-MCP is not clear, as it only lowered Pro levels at 1 DPI. 


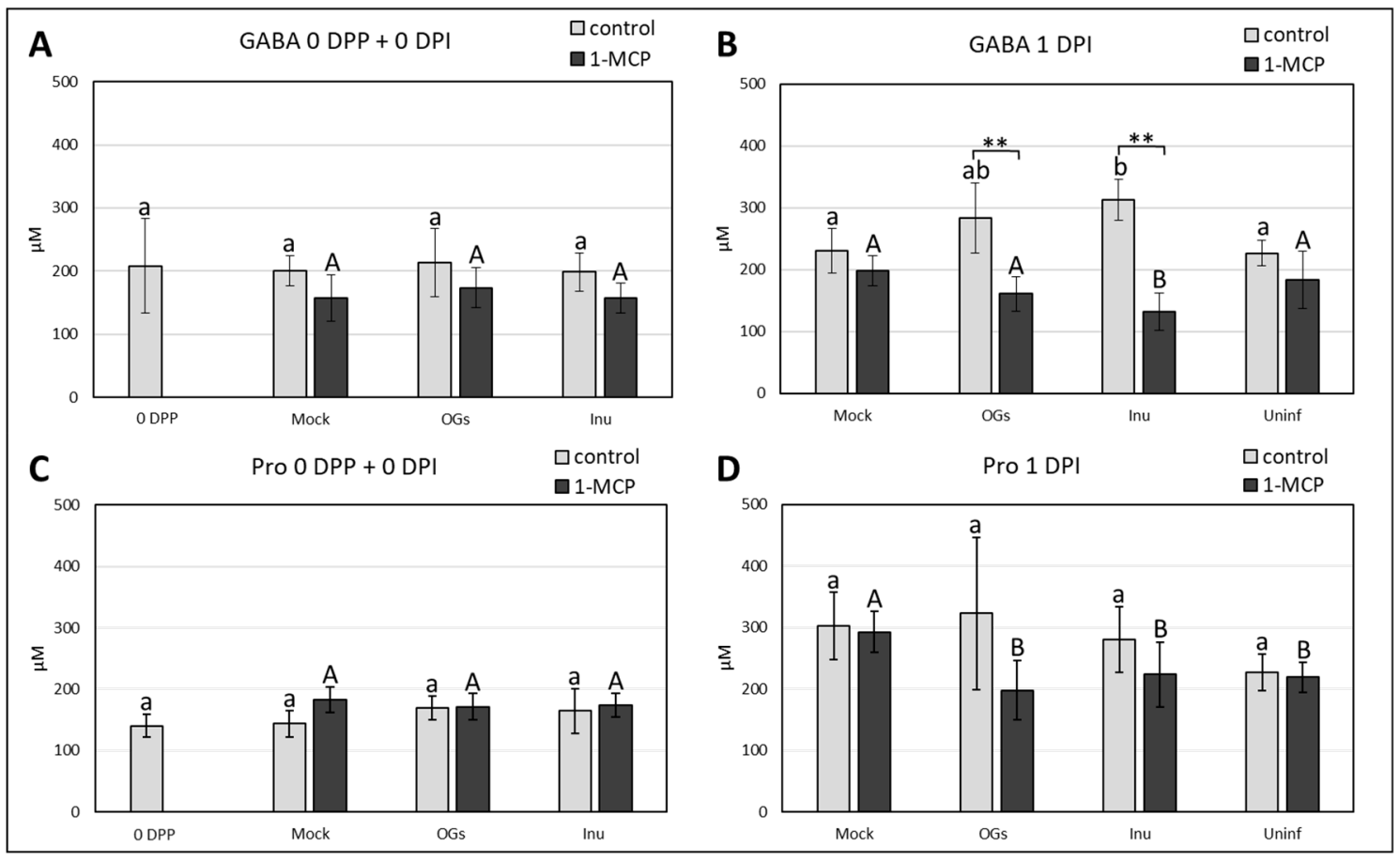

Figure 8. $\quad \gamma$-Aminobutyric acid (GABA) and Pro in primed and 1-MCP treated samples. Mock = water-primed leaves; OGs = OGs-primed leaves; Inu = chicory inulin-primed leaves; Uninf = Water-primed leaves inoculated with a mock solution (1/2 strength Potato dextrose broth). (A) GABA levels at 0 DPP and 0 DPI; (B) GABA levels at 1 DPI; (C) Pro levels at 0 DPP and 0 DPI; (D) Pro levels at 1 DPI. Bars marked with same letter(s) are not significant between each other, bars that have no letters in common indicate significance between treatments $(p<0.05$, one-way ANOVA followed by Tukey's post-hoc test). Lowercase letters refer to comparison between control treatments, capital letters refer to comparison between 1-MCP treatments. Asterisks indicate significance between control and 1-MCP conditions referring to the same priming treatment ${ }^{* *} p<0.01$, Student's $t$-test). Values represent the average \pm standard deviation of five biological replicates.

\section{Discussion}

\subsection{Fructan and OGs Elicit Defense Responses against Botrytis in Lettuce Leaves}

Many efforts are being made to develop alternatives to the use of toxic pesticides. Priming with natural products is a valuable option in this respect. The possibility of using sustainable, cheap, and easily available compounds like carbohydrates is receiving increasing attention [25], and illustrates the applicability of the Sweet Immunity concept in horticultural and postharvest practices $[64,65]$. We demonstrate that inulin-type fructans can successfully induce defense responses against Botrytis in lettuce (Figure 2). Our data show that the immunostimulatory effect can be associated with the specific saccharidic nature of the inulins ( $D P \geq 6$ ) (Figure 2). Both BFOs and chicory-derived inulins can enhance defense responses against Botrytis in lettuce, suggesting that inulin-type fructans have immunostimulating properties regardless of their origin. This further reinforces the conclusion that the ability to limit disease progression can be ascribed to the structural features of inulin (Figure 3). Lettuce is able to synthetize inulin-type fructans in stems and roots in modest amounts, but not in leaves [66]. Although there is no known fructan receptor and/or signaling pathway identified in plants, work in T84 human intestinal epithelial cell monolayers showed that inulin is able to bind and activate Toll-Like Receptor 2 (TLR2) and to a lesser extent TLR4, TLR5, TLR7, and TLR8 [67,68]. Such studies lead us to formulate the hypothesis that fructans may be perceived in plants as well, in the role of MAMPs or DAMPs [69] by a so far unknown sensor (TLR homologues are not present in plant genomes). Another option could be that the biological effects of fructans would involve their 
well-described interaction with membranes [70]. OGs are prototypical DAMPs able to elicit defenses against Botrytis cinerea in Arabidopsis and grape [71,72]. They may prime defenses upon cell wall damage [36]. We proved for the first time the effectiveness of OGs in inducing disease protection in lettuce (Figure 4) and optimized the best dosage (Figure S5) to induce protection, and used them as positive control.

\section{2. $\mathrm{H}_{2} \mathrm{O}_{2}$ Accumulates Following Fructans and OGs Treatments}

A common feature of plant responses to pathogens is the production and accumulation of reactive oxygen species (ROS) [73,74], and induction of ROS accumulation is widely documented in leaf tissues subjected to abiotic stress and exposed to DAMPs and MAMPs [71,75]. BFOs are able to induce $\mathrm{H}_{2} \mathrm{O}_{2}$ accumulation in tobacco leaves, with a peak at $6 \mathrm{~h}$ after treatment [57]. Our data showed a modest, but significant oxidative burst for inulin and OGs at $3 \mathrm{~h}$ after spraying and this level remained high for the subsequent $72 \mathrm{~h}$, although for inulin we could not detect significant differences anymore at $72 \mathrm{~h}$ (Figure 4). Overall, time-dependent ROS dynamics may greatly depend on the dosage and species considered [71,76]. Altogether, the increase in $\mathrm{H}_{2} \mathrm{O}_{2}$ levels after inulin priming might suggest it triggers a ROS-mediated plant defense response. As expected, ROS levels increase much more when the pathogen comes into play, as compared to pre-inoculation time-points (Figure 4). In general, ROS generation is associated with SA signaling, which is effective against biotrophs, whereas necrotrophs usually take advantage of it [77]. In Arabidopsis, OGs elicit an oxidative burst, but this burst is not required for the OG-induced resistance to B. cinerea [78]. Thus, it remains possible that the $\mathrm{H}_{2} \mathrm{O}_{2}$ induction observed in lettuce treated with OGs (Figure 4) is not a major factor against Botrytis. Therefore, it is difficult to say if this is also the case for the increase in $\mathrm{H}_{2} \mathrm{O}_{2}$ levels observed in inulin-treated leaves, and whether it is related to disease limitation or not. However, it was shown that timely and localized ROS induction at the early stages of the plant-pathogen interaction can be a resistance factor against a necrotroph such as Botrytis in tomato and bean $[79,80]$. This may be the case for our pathosystem as well, but further research is required to clarify this.

\subsection{Ethylene Is Involved in OGs and Fructan Priming in Lettuce}

Ethylene and JA are the most important phytohormones in modulating resistance against necrotrophs [14]. Ethylene was shown to be required for OGs-mediated Botrytis resistance in Arabidopsis [11], and our ethylene synthesis and signaling inhibitor (1-MCP and AVG) treatments suggest a similar case for lettuce (Figure 5, and Figure S4). It is also the first time that ethylene synthesis and signaling were studied in combination with fructan treatment. The fact that inulin-triggered disease limitation also seems to rely on ethylene signaling and synthesis is a novel finding. Perhaps the most interesting observation is that ethylene signaling and synthesis are predominantly playing an important role in primed leaves, because a 1-MCP and AVG treatment does not increase susceptibility in mock-treated leaves (Figure 5, and Figure S4). These data suggest that ethylene is not involved in basal immunity in water-treated lettuce leaves. Ethylene is known to be a resistance factor in leaves of several plant species against Botrytis (Arabidopsis, artemisia, tomato) [11,81,82]. However, it was also demonstrated that a 1-MCP application did not alter Botrytis resistance in pepper leaves in the absence of priming [83]. Taken together, our results add another layer of complexity regarding the role of ethylene during plant-necrotroph interactions, with many possible variations depending on the pathosystem as well as the stage of infection [20]. JA involvement in Botrytis resistance was demonstrated in species such as Arabidopsis and tomato [84,85]. Although we have not studied JA in our pathosystem, further research to clarify its involvement and possible interaction with the ethylene pathway in lettuce is warranted.

\subsection{OGs Induce Accumulation of Soluble Sugars before Botrytis Inoculation}

The changes in soluble sugars content after priming suggest that the OGs treatment triggers accumulation of Suc, Glc, and Fru in lettuce leaves (Figure 6A,C,E). To the best of our knowledge, 
it is the first time that soluble sugar dynamics are recorded after application of OGs and subsequent infection. On the other hand, inulin priming does not result in significant changes in the sugar pools before inoculation (Figure 6A,C,E), while the level of hexoses increased after infection (Figure 6D,F). These data reveal clear differences in how exogenous applications of OGs and inulins influence sugar metabolism. Glc and Suc, but not Fru, levels dropped drastically in OGs samples at 1 DPI (Figure 6B,D,F). This may indicate an increase in the use of Glc moieties after pathogen perception in leaves pretreated with OGs. It will be interesting to address future studies on how OGs application impacts apoplastic sugar concentrations.

\subsection{Suc Dynamics Are Modulated by Ethylene Signaling}

The interaction between ethylene and sugar metabolism represents an interesting topic in present day plant physiology, although the regulatory mechanisms may greatly depend on the source and sink status of the organs, the developmental stage, and on the species studied [86,87]. On the one hand, ethylene stimulates senescence in aging leaves and ripening in fruits, while on the other hand, it is essential for normal plant development, and for many physiological processes, including photosynthesis $[86,87]$. We observed a strong negative effect of 1-MCP on the Suc pool both before and after inoculation, independently of priming (Figure 6A,B). This result indicates that an intact ethylene signaling pathway is required to maintain physiological Suc levels in mature lettuce leaves. Given the importance of Suc as a building block for antimicrobial compounds and as a signaling molecule in plant defense $[38,88,89]$, a decrease in Suc levels may be one of the explanations for the increased susceptibility observed in OGs and inulin treated leaves after the 1-MCP application. This leaves us with a question: why is such susceptibility increase not detected in mock-treated plants? It is also worthwhile to note that 1-MCP strongly decreases all soluble sugars in inulin primed samples after infection, suggesting that inulin priming relies on ethylene-dependent sugar homeostasis (Figure 7B,D,F). Notably, 1-MCP does not have a major influence on the Fru pool (Figure 6E,F). In contrast to Fru, Glc levels can drop fast, because it is rapidly channeled into the OPPP pathway by glucose 6-phosphate dehydrogenase (G6PD) activity [90]. This pathway provides NADPH (Nicotinamide Adenine Dinucleotide Phosphate) for reductive biosynthesis and maintenance of the cellular redox state, crucial during defense responses [91].

\subsection{Ethylene Differentially Controls Cell Wall and Vacuolar Invertase Activities}

Invertases can modulate Suc/hexose balances. As such, they can greatly influence sugar metabolism and sugar signaling events. Our data on acidic invertase activities revealed no significant changes following priming treatments (Figure 7A,C), although we cannot rule out the possibility that we missed an earlier time window of invertase (in)activation. There is an extensive body of evidence that CWI activity increases following pathogen perception in different pathosystems [92-94], suggesting that CWI contributes to pathogen resistance [95]. Unexpectedly, we found an increase in CWI activity in uninfected samples, as compared to the other treatments at 1 DPI (Figure 7B). A first interpretation is that the situation in lettuce may be different as compared to the above-mentioned species. Another possible explanation could lie in the sampling. Whereas most studies used a full-leaf sampling, taking into account the main vein, our sampling was much narrower around the lesion and possibly not representative for a full-leaf context.

Ethylene negatively affects CWI activity in cell suspensions of Chenopodium rubrum [96] and increased CWI activity is observed in Arabidopsis ein4 mutants [97], suggesting that ethylene suppresses CWI activity. Accordingly, the 1-MCP application in our work led to a drastic increase in CWI activity (Figure 8B). However, 1-MCP seems unable to release the ethylene suppression of CWI activity in uninfected controls. Lowered CWI activities at the very early stages of infection may be advantageous to limit hexoses in the apoplastic environment, counteracting the spreading of Botrytis [98]. Accordingly, cases of decreased infection symptoms development following CWI repression are documented [99]. Such a mechanism may be advantageous for the plant, especially if combined with accelerated 
Suc uptake and intracellular processing by VI. Accordingly, VI activities are significantly higher in water-primed and infected leaves as compared to uninfected leaves (Figure 7D), while the opposite reaction can be observed for CWI. Interestingly, inulin seems to counteract this effect on VI (Figure 7D). It is not clear whether VI has a positive or negative role for the plant in our pathosystem, given that it is repressed by inulin but not affected by OGs at 1 DPI (Figure 7D). Moreover, the 1-MCP treatment enhanced VI activity at 0 DPI in all treatments, but had no effect on infected samples at 1 DPI (Figure 7C,D). These data suggest that ethylene plays a negative role in regulating both CWI and VI [97], but after pathogen perception this control mechanism seems to be uncoupled. It remains to be tested whether such uncoupling is due to the pathogens' capacity to change soluble sugars availability, by direct uptake or by using dedicated effectors.

\subsection{Inulin Treatments Induce GABA Accumulation During Botrytis Infection}

GABA plays a central role at the interface of $C$ and $N$ metabolism [100]. In the tomato-Botrytis pathosystem, the GABA shunt was shown to be critical in replenishing the TCA (Tricarboxylic Acid) cycle and eventually maintaining cell viability during Botrytis infection in ABA-deficient sitiens mutants of tomato [101]. The increase in GABA levels in inulin-treated leaves after infection may help to explain the observed enhanced defense responses (Figure $8 \mathrm{~B}$ ) in view of the model proposed by Seifi and colleagues [101]. In line with their work, GABA and $\mathrm{H}_{2} \mathrm{O}_{2}$ may fulfil complementary roles, maintaining cell viability on the one hand and preventing rapid spreading of the pathogen on the other hand [101]. Given that inulin priming induces both GABA and $\mathrm{H}_{2} \mathrm{O}_{2}$ accumulation, it will be interesting to dedicate future research to the link between $\mathrm{ABA}$ and fructan priming/perception. Interestingly, 1-MCP impairs GABA accumulation in OGs and inulin treated leaves after infection (Figure 8B), indicating that ethylene signaling mediates GABA accumulation after a Botrytis infection. To the best of our knowledge, no reports are available on GABA induction by ethylene in the context of biotic stress. However, it was shown that GABA can induce ethylene synthesis in sunflower [102], raising the hypothesis of a positive feedback mechanism between these two signaling compounds following priming events.

Pro accumulation and metabolism is known to contribute to plant resistance against biotrophs [103], and Pro dehydrogenase mutants were shown to have impaired resistance against both Pseudomonas syringae and Botrytis cinerea [101,104]. Botrytis infection stimulates Pro accumulation in lettuce (Figure 8D), but the lack of significant differences between mock and primed samples suggest that Pro concentration does not play a significant role in our pathosystem, at least at the early stages of infection.

\section{Materials and Methods}

\subsection{Biological Material}

Lettuce plants (Lactuca sativa L. cv. Gisela) were grown in a Conviron ${ }^{\circledR}$ chamber with a temperature of $21 / 16^{\circ} \mathrm{C}$ (day /night), $12 \mathrm{~h} / 12 \mathrm{~h}$ day $/$ night light regime, light intensity of $170 \mu \mathrm{mol} \cdot \mathrm{m}^{-2} \cdot \mathrm{s}^{-1}$, and $80 \%$ RH (Relative Humidity). For experiments, fully mature leaves from 45 days old plants were used. Botrytis cinerea B05.10 strain was used in our trials [60], provided by Dr. Barbara De Coninck (KU Leuven, Division of Crop Biotechnics, Leuven, Belgium), and cultivated on potato dextrose agar plates (PDA) at $18^{\circ} \mathrm{C}$. Before inoculations, spores were harvested from plates and diluted in half-strength potato dextrose broth (PDB) to a final concentration of $5 \times 10^{5}$ spores $\mathrm{mL}^{-1}$ with the help of a stereomicroscope Olympus 3000 (Olympus, Tokyo, Japan).

\subsection{Priming and Infection Assays}

For priming treatments, four mature leaves from each plant were selected, and sprayed with different solutions. From 4 to 6 plants per treatment were used. All the solutions were prepared in Milli $Q$ water supplemented with $0.0001 \%$ Tween 20 as surfactant. Three days after priming, two $5 \mu \mathrm{L}$ 
drops of the above mentioned Botrytis solution were placed on detached leaves (Figure 9). Inoculated leaves were placed in Petri plates of $15 \mathrm{~cm}$ diameter, lined with wet tissue paper and sealed with parafilm. Plates were placed in an incubator at $18^{\circ} \mathrm{C}$ for 4 days before disease scoring. Necrotic lesion area was calculated by using ImageJ program (https://imagej.nih.gov/ij/) as described [72]. Lesions were then assigned to one of the 6 severity categories as defined in Table 1.

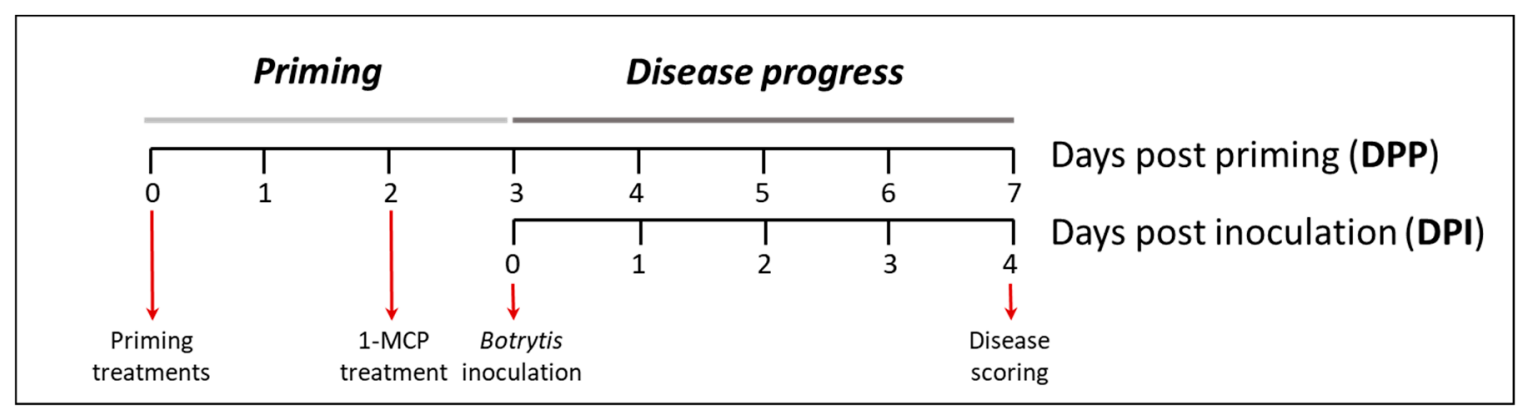

Figure 9. Schematic representation of the experimental design used for the priming and disease scoring performed in this study.

Table 1. Description of the severity classes implemented in the disease scorings done in this work with corresponding representative pictures. Scale bars $=1 \mathrm{~cm}$.

\begin{tabular}{|c|c|c|c|c|c|c|}
\hline Class & 1 & 2 & 3 & 4 & 5 & 6 \\
\hline \multicolumn{7}{|l|}{ picture } \\
\hline description & $\begin{array}{l}\text { - Failed } \\
\text { penetration of } \\
\text { the pathogen. } \\
\text { - Small and } \\
\text { irregular signs } \\
\text { of necrosis } \\
\text { unable to } \\
\text { converge in a } \\
\text { unique } \\
\text { infection spot. }\end{array}$ & $\begin{array}{l}\text { - Spreading } \\
\text { spot with } \\
\text { irregular form, } \\
\text { limited to the } \\
\text { surrounding } \\
\text { mesophyll. } \\
\text { - Light brown } \\
\text { shape. }\end{array}$ & $\begin{array}{l}\text { - Spreading } \\
\text { spot with } \\
\text { defined } \\
\text { circular shape, } \\
\text { confined } \\
\text { between the } \\
\text { secondary } \\
\text { veins. } \\
\text { - Brown and } \\
\text { moisty shape. }\end{array}$ & $\begin{array}{l}\text { - Spreading } \\
\text { lesion with } \\
\text { circular sharp, } \\
\text { spreading } \\
\text { from the } \\
\text { mesophyll to } \\
\text { the secondary } \\
\text { veins. } \\
\text { - Brown and } \\
\text { moisty shape. }\end{array}$ & $\begin{array}{l}\text { - Spreading } \\
\text { lesion with } \\
\text { circular or } \\
\text { elliptical shape. } \\
\text { - Brown and } \\
\text { moisty shape, } \\
\text { lesion area } \\
\text { characterized by } \\
\text { rings of necrotic } \\
\text { tissue. }\end{array}$ & $\begin{array}{c}\text { - Spreading lesion } \\
\text { with elliptical or } \\
\text { irregular shape, } \\
\text { widely spreaded } \\
\text { across secondary } \\
\text { veins and affecting } \\
\text { the midrib. } \\
\text { - Dark-brown and } \\
\text { moisty shape with } \\
\text { sporulation spots. }\end{array}$ \\
\hline
\end{tabular}

\section{3. $\mathrm{H}_{2} \mathrm{O}_{2}$ Assay}

Detection of $\mathrm{H}_{2} \mathrm{O}_{2}$ was performed according to Daudi et al. [61], with minor modifications. Leaves were divided into 4 segments in order to facilitate infiltration. Briefly, leaf segments were infiltrated with DAB solution at $200 \mathrm{mBar}$ until tissues were completely infiltrated, and then incubated in dark for $4 \mathrm{~h}$. Subsequently, leaves were de-stained in an ethanol:acetic acid:glycerol 3:1:1 solution and photographed on a white background. ROS quantification was performed with a pixel analysis method by converting images to grey scale, as described [105].

\subsection{1-MCP and AVG Treatments}

Anti-ethylene treatments were done with an ethylene perception inhibitor (1-MCP; binds to the ethylene receptors) and an ethylene biosynthesis inhibitor (AVG; blocks ACC-synthase activity) $24 \mathrm{~h}$ before inoculation. Lettuce plants were placed in airtight sealed Plexiglas boxes and administered with 10 ppm 1-MCP (1-methylcyclopropene; a kind gift from AgroFresh, Philadelphia, PA, USA) for $24 \mathrm{~h}$. Dry 1-MCP powder was wetted with water after sealing the boxes by gently shaking. For the AVG treatments, plants were sprayed $4 \mathrm{~h}$ before inoculation with $10 \mu \mathrm{M}$ AVG (aminoethoxyvinylglycine; Sigma, St. Louis, MO, USA) supplemented with $0.0001 \%$ Tween 20 as surfactant. Leaves were detached $24 \mathrm{~h}$ after the 1-MCP or AVG treatment and prior to the inoculation treatment. 


\subsection{Carbohydrate Extraction, Processing, and Analysis}

To extract and quantify Glc, Fru and Suc, a circular shape $(3.5 \mathrm{~cm}$ diameter) of leaf material with an approximate weight of $200 \mathrm{mg}$ was taken from primed and infected leaves. In the case of infected leaves, a circular leaf disc ( $3.5 \mathrm{~cm}$ diameter) surrounding the lesion was sampled. This material was ground in liquid nitrogen and then heated at $90{ }^{\circ} \mathrm{C}$ in $0.5 \mathrm{~mL}$ water, and subsequently passed through Dowex ${ }^{\circledR}$ anion and cation exchange resins. Rhamnose $20 \mu \mathrm{M}$ was added as internal standard. The sample was then analyzed by HPAEC-IPAD Dionex 3000 (Thermofisher, Whaltam, MA, USA) according to Shiomi et al., [106].

BFOs were extracted from freeze-dried burdock (Arctium lappa) roots according to the protocol described by Hao et al. [107] with minor modifications. For enzymatic hydrolysis treatments, we used a -fructan 1-exohydrolase from chicory [108] immobilized on a Concanavalin-A Sephadex resin (GE Healthcare, Chicago, IL, USA). BFOs were dialyzed with $1 \mathrm{kDa}$ cutoff Spectra/Por membrane (Repligen, Waltham, MA, USA).

OGs were extracted from polygalacturonic acid sodium salt (Sigma). $800 \mathrm{mg}$ of powder were incubated with $10 \mathrm{mg}$ of pectinase extracted from Aspergillus niger ( 0.71 units/mg, Polylab, Kundli, India) in $60 \mathrm{~mL} \mathrm{NaAc}$ buffer $\mathrm{pH} 5$ for $60 \mathrm{~min}$ at $40{ }^{\circ} \mathrm{C}$. The solution was then boiled for $8 \mathrm{~min}$ at $90^{\circ} \mathrm{C}$ and centrifuged $(20 \mathrm{~min}, 40,000 \times \mathrm{g})$. The resulting supernatant was diluted in $40 \mathrm{~mL}$ acetone and centrifuged $(15 \mathrm{~min}, 14,000 \times g)$. This step was repeated twice. Finally, the obtained pellet was washed two times in $80 \%$ acetone and dried with the use of a liofilizator (LSL Secfroid, Aclens, Switzerland).

\subsection{Acidic Invertase Activity Assays}

For VI and CWI activity assays, $50 \mathrm{mg}$ of grounded lettuce leaf material was dissolved in $150 \mu \mathrm{L}$ of extraction buffer $50 \mathrm{mM}$ NaAc buffer at pH 5, with $10 \mathrm{mM} \mathrm{NaHSO}_{3}, 0.01 \%$ Polyclar and $2 \mathrm{mM}$ $\beta$-mercaptoethanol ( $\beta$-ME). $1 \mu \mathrm{L}$ of $200 \mathrm{mM}$ phenylmethylsulfonyl fluoride (PMSF) was added to each sample. The homogenized solution was centrifuged at $13,000 \times g$ for $15 \mathrm{~min}$, and pellet (CWI-enriched) and supernatant (VI-enriched) were separated. De-salting and invertase activity measurements were carried out as described [109].

\subsection{GABA Extraction and Analysis}

GABA was extracted from $50 \mathrm{mg}$ of ground lettuce leaf in $100 \mu \mathrm{L}$ water and subsequently sonicated for $10 \mathrm{~min}$. Samples were then centrifuged at $13,000 \times g$ for $5 \mathrm{~min}$. $45 \mu \mathrm{L}$ of supernatant was diluted with $30 \mu \mathrm{L}$ of a $25 \mathrm{mM}$ NorValine solution (used as internal standard). GABA was then injected on a reverse HPLC system (Shimadzu, Kyoto, Japan) and derivatized before column injection as O-Phtalaldehyde and separated on a YMC Triart C18 column with the use of buffer "A" $(50 \mathrm{mM}$ $\mathrm{KH}_{2} \mathrm{PO}_{4} \mathrm{pH}$ 6.5, 0.7\% v/v Tetrahydrofurane) and buffer "B" (Acetonitrile:MeOH:water 45:40:15) with the following gradient: from 0 to $6 \mathrm{~min}=96 \% \mathrm{~A} 4 \% \mathrm{~B}$; from 6 to $18 \mathrm{~min}=92 \% \mathrm{~A} 8 \% \mathrm{~B}$; from 18 to $32 \mathrm{~min}=85 \% \mathrm{~A} 15 \% \mathrm{~B}$; from 32 to $50 \mathrm{~min}=67 \% \mathrm{~A} 33 \% \mathrm{~B}$; from 50 to $53 \mathrm{~min}=100 \% \mathrm{~B}$. GABA was detected with a fluorescence detector at $\lambda_{\mathrm{ex}}=230 \mathrm{~nm}$ and $\lambda_{\mathrm{em}}=450 \mathrm{~nm}$.

\subsection{Proline Extraction and Analysis}

Pro was extracted from $50 \mathrm{mg}$ of ground lettuce leaf with $100 \mu \mathrm{L}$ water and subsequently sonicated for $10 \mathrm{~min}$. Samples were then centrifuged at $13,000 \times g$ for $5 \mathrm{~min}$. The supernatant was diluted 10 times in water containing $20 \mu \mathrm{M}$ serine (used as internal standard). The sample was then vortexed and centrifuged at $13,000 \times g$ for $5 \mathrm{~min}$, transferred to a vial with a conical glass insert and analyzed by HPAEC-IPAD (Thermofisher, USA) in order to determine the Pro content after separation on a CarboPac ${ }^{\circledR}$ PA100 anion exchange column. The flow rate was $0.25 \mathrm{~mL} \cdot \mathrm{min}^{-1}$. Pro was eluted with the following gradient: $9 \mathrm{mM} \mathrm{NaOH}$ from $0 \mathrm{~min}$ to $15 \mathrm{~min} ; 0.5 \mathrm{M} \mathrm{NaAc}$ from 15 to $17 \mathrm{~min} ; 90 \mathrm{mM}$ $\mathrm{NaOH}$ from 17 to $23 \mathrm{~min}$. Quantification was performed on the peak areas with the external standard, consisting of $20 \mu \mathrm{M}$ Pro. 


\subsection{Statistical Analysis}

Disease scoring data were analyzed by using two-tailed Mann-Whitney $u$-test for categorized data. Other data were analyzed by using one-way ANOVA followed by Tukey's post-hoc test, or two-tailed Student's $t$-test when appropriate.

\section{Conclusions}

In this study, we show that inulin-type fructans are promising priming agents in the context of disease control, an observation that should stimulate research on fructans and on other carbohydrates as potential substitutes for pesticides use in field and postharvest applications [27,28]. In this sense, an important future task will be to understand which natural priming agents are the most efficient disease suppressors in specific crops, as well as exploring possibilities of inducing cross-tolerance towards abiotic and biotic stresses. The observed changes in $\mathrm{H}_{2} \mathrm{O}_{2}$ accumulation, sugar metabolism, and GABA dynamics, as well as the clear connections with ethylene signaling, opens new research avenues to address the role of fructans in the sweet immunity context.

Supplementary Materials: Supplementary materials can be found at http:/ / www.mdpi.com/1422-0067/20/5/ 1052/s1. Figure S1. Suc, Fru and Glc application at $50 \mathrm{mM}$ concentration does not induce protective effects on lettuce leaves. Asterisks indicate significance against mock at $p<0.05$ according to non-parametrical, two-tailed, Mann-Whitney $u$-test, $n \geq 16$. This experiment was repeated three times with consistent results. Figure S2. Representative pictures of Botrytis cinerea growth assay on PDA plates supplemented with $0.5,1$ and $5 \mathrm{~g} \cdot \mathrm{L}^{-1}$ inulin, with pictures taken 7 and 12 days (D) after plate inoculation. Bars $=1 \mathrm{~cm}$. Figure S3. Representative pictures of DAB-stained lettuce leaves after priming and during infection. $3 \mathrm{hPP}=3 \mathrm{~h}$ post priming; $1 \mathrm{DPP}=1$ day post priming; $0 \mathrm{DPI}=0$ days post inoculation; $1 \mathrm{DPI}=1$ day post inoculation. Bars $=1 \mathrm{~cm}$. Figure S4. Effect of AVG treatment on disease susceptibility against B. cinerea. (A) Disease scoring results of primed leaves not treated with AVG; (B) Disease scoring results of primed leaves treated with AVG before inoculation. Asterisks indicate significant differences from mock $(p<0.05$, Mann-Whitney $u$-test). This experiment was repeated three times with consistent results; (C) Representative pictures of Botrytis cinerea growth assay on PDA plates with and without $10 \mu \mathrm{M}$ AVG, with pictures taken 7 and 12 days; (D) After plate inoculation. Bars $=1 \mathrm{~cm}$. Figure S5. Dose-response effect of OGs priming on lettuce leaves. Numbers used refer to $\mathrm{g} \cdot \mathrm{L}^{-1}$ concentration. Asterisks indicate significant differences from mock at $p<0.05$ according to non-parametrical, two-tailed, Mann-Whitney $u$-test. This experiment was repeated two times with consistent results.

Author Contributions: Conceptualization, Ł.P.T., M.H., and W.V.d.E.; Methodology, Ł.P.T., W.V.d.E., M.H., and B.V.d.P.; Software, Ł.P.T.; Validation, Ł.P.T.; Formal analysis, Ł.P.T. and W.V.d.E.; Investigation, Ł.P.T. and W.V.d.E.; Resources, W.V.d.E., M.H., and B.V.d.P.; Data Curation, Ł.P.T. and W.V.d.E.; Writing-Original Draft Preparation, Ł.P.T.; Writing-Review \& Editing, Ł.P.T., W.V.d.E., M.H., and B.V.d.P.; Visualization. Ł.P.T.; Supervision, W.V.d.E.; Project Administration, W.V.d.E.; Funding Acquisition, M.H. and W.V.d.E.

Funding: The authors acknowledge FWO Vlaanderen for financial support (grant number G0A4915N).

Acknowledgments: The authors are grateful to Rudy Vergauwen, Tom Struyf (Lab of Molecular Plant Biology, KU Leuven), Veerle Verdoodt and Maarten Houben (Lab of Molecular Plant Hormone Physiology, KU Leuven) for technical assistance. We are also grateful to Dr. Santiago Signorelli for helping with the graphic abstract.

Conflicts of Interest: The authors declare no conflicts of interest.

\section{References}

1. Savary, S.; Ficke, A.; Aubertot, J.N.; Hollier, C. Crop losses due to diseases and their implications for global food production losses and food security. Food Secur. 2012, 4, 519-537. [CrossRef]

2. Wilson, C.; Tisdell, C. Why farmers continue to use pesticides despite environmental, health and sustainability costs. Ecol. Econ. 2001, 39, 449-462. [CrossRef]

3. McDougall, P. The Cost of New Agrochemical Product Discovery, Development and Registration in 1995, 2000 and 2005-8; R \& D Expenditure in 2007 and Expectations for 2012 Final Report; Phillips McDougall: Pathhead, UK, 2010.

4. Pal, K.K.; Mc Spadden Gardener, B. Biological Control of Plant Pathogens. Plant Health Instr. 2006, 1-25. [CrossRef] 
5. Vos, C.M.; Yang, Y.; De Coninck, B.; Cammue, B.P.A. Fungal (-like) biocontrol organisms in tomato disease control. Biol. Control 2014, 74, 65-81. [CrossRef]

6. Conrath, U. Molecular aspects of defence priming. Trends Plant Sci. 2011, 16, 524-531. [CrossRef] [PubMed]

7. Martinez-Medina, A.; Flors, V.; Heil, M.; Mauch-Mani, B.; Pieterse, C.M.J.; Pozo, M.J.; Ton, J.; van Dam, N.M.; Conrath, U. Recognizing Plant Defense Priming. Trends Plant Sci. 2016, 21, 818-822. [CrossRef] [PubMed]

8. Romanazzi, G.; Sanzani, S.M.; Bi, Y.; Tian, S.; Gutiérrez Martínez, P.; Alkan, N. Induced resistance to control postharvest decay of fruit and vegetables. Postharvest Biol. Technol. 2016, 122, 82-94. [CrossRef]

9. Poimenidou, S.V.; Bikouli, V.C.; Gardeli, C.; Mitsi, C.; Tarantilis, P.A.; Nychas, G.J.; Skandamis, P.N. Effect of single or combined chemical and natural antimicrobial interventions on Escherichia coli O157, H7, total microbiota and color of packaged spinach and lettuce. Int. J. Food Microbiol. 2016, 220, 6-18. [CrossRef] [PubMed]

10. Kelly, G. Inulin-Type Prebiotics-A Review: Part 1. Altern. Med. Rev. 2008, 13, 315-329. [PubMed]

11. Gravino, M.; Savatin, D.V.; Macone, A.; de Lorenzo, G. Ethylene production in Botrytis cinerea- and oligogalacturonide-induced immunity requires calcium-dependent protein kinases. Plant J. 2015, 84, 1073-1086. [CrossRef] [PubMed]

12. Van Aubel, G.; Cambier, P.; Dieu, M.; van Cutsem, P. Plant immunity induced by COS-OGA elicitor is a cumulative process that involves salicylic acid. Plant Sci. 2016, 247, 60-70. [CrossRef] [PubMed]

13. Schenk, S.T.; Schikora, A. AHL-priming functions via oxylipin and salicylic acid. Front. Plant Sci. 2015, 5, 1-7. [CrossRef] [PubMed]

14. Pieterse, C.M.J.; van der Does, D.; Zamioudis, C.; Leon-Reyes, A.; van Wees, S.C.M. Hormonal Modulation of Plant Immunity. Annu. Rev. Cell Dev. Biol. 2012, 28, 489-521. [CrossRef] [PubMed]

15. Yan, C.; Xie, D. Jasmonate in plant defence: Sentinel or double agent? Plant Biotechnol. J. 2015, 13, $1233-1240$. [CrossRef] [PubMed]

16. Glazebrook, J. Contrasting Mechanisms of Defense Against Biotrophic and Necrotrophic Pathogens. Annu. Rev. Phytopathol. 2005, 43, 205-227. [CrossRef] [PubMed]

17. Yang, L.; Li, B.; Zheng, X.Y.; Li, J.; Yang, M.; Dong, X.; He, G.; An, C.; Deng, X.W. Salicylic acid biosynthesis is enhanced and contributes to increased biotrophic pathogen resistance in Arabidopsis hybrids. Nat. Commun. 2015, 6, 7309. [CrossRef] [PubMed]

18. Trusov, Y.; Sewelam, N.; Rookes, J.E.; Kunkel, M.; Nowak, E.; Schenk, P.M.; Botella, J.R. Heterotrimeric G proteins-mediated resistance to necrotrophic pathogens includes mechanisms independent of salicylic acid-, jasmonic acid/ethylene- and abscisic acid-mediated defense signaling. Plant J. 2009, 58, 69-81. [CrossRef] [PubMed]

19. Di, X.; Gomila, J.; Takken, F.L.W. Involvement of salicylic acid, ethylene and jasmonic acid signalling pathways in the susceptibility of tomato to Fusarium oxysporum. Mol. Plant Pathol. 2017, 1, 1024-1035. [CrossRef] [PubMed]

20. Geraats, B.P.J.; Bakker, P.A.H.M.; Linthorst, H.J.M.; Hoekstra, J.; van Loon, L.C. The enhanced disease susceptibility phenotype of ethylene-insensitive tobacco cannot be counteracted by inducing resistance or application of bacterial antagonists. Physiol. Mol. Plant Pathol. 2007, 70, 77-87. [CrossRef]

21. Liu, G.; Kennedy, R.; Greenshields, D.L.; Peng, G.; Forseille, L.; Selvaraj, G.; Wei, Y. Detached and Attached Arabidopsis Leaf Assays Reveal Distinctive Defense Responses Against Hemibiotrophic Colletotrichum spp. Mol. Plant.-Microbe Interact. 2007, 20, 1308-1319. [CrossRef] [PubMed]

22. Galletti, R.; de Lorenzo, G.; Ferrari, S. Host-derived signals activate plant innate immunity. Plant Signal. Behav. 2009, 4, 33-34. [CrossRef] [PubMed]

23. Pastor, V.; Luna, E.; Mauch-Mani, B.; Ton, J.; Flors, V. Primed plants do not forget. Environ. Exp. Bot. 2013, 94, 46-56. [CrossRef]

24. Hann, C.T.; Bequette, C.J.; Dombrowski, J.E.; Stratmann, J.W. Methanol and ethanol modulate responses to danger- and microbe-associated molecular patterns. Front. Plant Sci. 2014, 5, 550. [CrossRef] [PubMed]

25. Trouvelot, S.; Heloir, M.-C.; Poinssot, B.; Gauthier, A.; Paris, F.; Guillier, C.; Combier, M.; Trda, L.; Daire, X.; Adrian, M. Carbohydrates in plant immunity and plant protection: Roles and potential application as foliar sprays. Front. Plant Sci. 2014, 5, 592. [CrossRef] [PubMed] 
26. Chaliha, C.; Rugen, M.D.; Field, R.A.; Kalita, E. Glycans as Modulators of Plant Defense Against Filamentous Pathogens. Front. Plant Sci. 2018, 9, 928. [CrossRef] [PubMed]

27. Lastdrager, J.; Hanson, J.; Smeekens, S. Sugar signals and the control of plant growth and development. J. Exp. Bot. 2014, 65, 799-807. [CrossRef] [PubMed]

28. Li, L.; Sheen, J. Dynamic and diverse sugar signaling. Curr. Opin. Plant Biol. 2016, 33, 116-125. [CrossRef] [PubMed]

29. Yu, S.; Li, C.; Zhou, C.M.; Zhang, T.Q.; Lian, H.; Sun, Y.; Wu, J.; Huang, J.; Wang, G.; Wang, J.W. Sugar is an endogenous cue for juvenile-to-adult phase transition in plants. eLife 2013, 2, e00269. [CrossRef] [PubMed]

30. Mason, M.G.; Ross, J.J.; Babst, B.A.; Wienclaw, B.N.; Beveridge, C.A. Sugar demand, not auxin, is the initial regulator of apical dominance. Proc. Natl. Acad. Sci. USA 2014, 111, 6092-6097. [CrossRef] [PubMed]

31. Mudgil, Y.; Karve, A.; Teixeira, P.J.P.L.; Jiang, K.; Tunc-Ozdemir, M.; Jones, A.M. Photosynthate Regulation of the Root System Architecture Mediated by the Heterotrimeric G Protein Complex in Arabidopsis. Front. Plant Sci. 2016, 7, 1255. [CrossRef] [PubMed]

32. Morkunas, I.; Ratajczak, L. The role of sugar signaling in plant defense responses against fungal pathogens. Acta Physiol. Plant. 2014, 36, 1607-1619. [CrossRef]

33. Tarkowski, Ł.P.; Van den Ende, W. Cold tolerance triggered by soluble sugars: A multifaceted countermeasure. Front. Plant Sci. 2015, 6, 203. [CrossRef] [PubMed]

34. Yamada, K.; Saijo, Y.; Nakagami, H.; Takano, Y. Regulation of sugar transporter activity for antibacterial defense in Arabidopsis. Science 2016, 354, 1427-1430. [CrossRef] [PubMed]

35. Bolouri Moghaddam, M.R.; Van den Ende, W. Sweet immunity in the plant circadian regulatory network. J. Exp. Bot. 2013, 64, 1439-1449. [CrossRef] [PubMed]

36. Ferrari, S.; Savatin, D.V.; Gramegna, G.; Cervone, F.; De Lorenzo, G. Oligogalacturonides: Plant damage-associated molecular patterns and regulators of growth and development. Front. Plant Sci. 2013, 4, 49. [CrossRef] [PubMed]

37. de Souza, C.A.; Li, S.; Lin, A.Z.; Boutrot, F.; Grossmann, G.; Zipfel, C.; Somerville, S.C. Cellulose-Derived Oligomers Act as Damage-Associated Molecular Patterns and Trigger Defense-Like Responses. Plant Physiol. 2017, 173, 2383-2398. [CrossRef] [PubMed]

38. Morkunas, I.; Marczak, Ł.; Stachowiak, J.; Stobiecki, M. Sucrose-induced lupine defense against Fusarium oxysporum: Sucrose-stimulated accumulation of isoflavonoids as a defense response of lupine to Fusarium oxysporum. Plant Physiol. Biochem. 2005, 43, 363-373. [CrossRef] [PubMed]

39. Bolouri Moghaddam, M.R.; Van den Ende, W. Sugars, the clock and transition to flowering. Front. Plant Sci. 2013, 4, 22. [PubMed]

40. Wan, H.; Wu, L.; Yang, Y.; Zhou, G.; Ruan, Y.L. Evolution of Sucrose Metabolism: The Dichotomy of Invertases and Beyond. Trends Plant Sci. 2018, 23, 163-177. [CrossRef] [PubMed]

41. Bonfig, K.B.; Gabler, A.; Simon, U.K.; Luschin-Ebengreuth, N.; Hatz, M.; Berger, S.; Muhammad, N.; Zeier, J.; Sinha, A.K.; Roitsch, T. Post-translational derepression of invertase activity in source leaves via down-regulation of invertase inhibitor expression is part of the plant defense response. Mol. Plant. 2010, 3, 1037-1048. [CrossRef] [PubMed]

42. Albacete, A.; Cantero-Navarro, E.; Großkinsky, D.K.; Arias, C.L.; Balibrea, M.E.; Bru, R.; Fragner, L.; Ghanem, M.E.; de La Cruz González, M.; Hernández, J.A.; et al. Ectopic overexpression of the cell wall invertase gene CIN1 leads to dehydration avoidance in tomato. J. Exp. Bot. 2015, 66, 863-878. [CrossRef] [PubMed]

43. Dahro, B.; Wang, F.; Peng, T.; Liu, J.H. PtrA/NINV, an Alkaline/neutral invertase gene of Poncirus trifoliata, confers enhanced tolerance to multiple abiotic stresses by modulating ROS levels and maintaining photosynthetic efficiency. BMC Plant Biol. 2016, 16, 76. [CrossRef] [PubMed]

44. Sturm, A. Invertases. Primary Structures, Functions, and Roles in Plant Development and Sucrose Partitioning. Plant Physiol. 1999, 121, 1-8. [CrossRef] [PubMed]

45. Hendry, G.A.F. Evolutionary origins and natural functions of fructans - a climatological, biogeographic and mechanistic appraisal. New Phytol. 1993, 123, 3-14. [CrossRef]

46. Mellado-Mojica, E.; Gonzalez de la Vara, L.E.; Lopez, M.G. Fructan active enzymes (FAZY) activities and biosynthesis of fructooligosaccharides in the vacuoles of Agave tequilana Weber Blue variety plants of different age. Planta 2017, 245, 265-281. [CrossRef] [PubMed] 
47. Valluru, R.; Lammens, W.; Claupein, W.; Van den Ende, W. Freezing tolerance by vesicle-mediated fructan transport. Trends Plant Sci. 2008, 13, 409-414. [CrossRef] [PubMed]

48. Vijn, I.; Smeekens, S. Fructan: More Than a Reserve Carbohydrate? Plant Physiol. 1999, 120, 351-360. [CrossRef] [PubMed]

49. Livingston, D.P.; Hincha, D.K.; Heyer, A.G. Fructan and its relationship to abiotic stress tolerance in plants. Cell. Mol. Life Sci. 2009, 66, 2007-2023. [CrossRef] [PubMed]

50. Amiard, V.; Morvan-Bertrand, A.; Billard, J.-P.; Huault, C.; Keller, F.; Prud'homme, M.-P. Fructans, but not the sucrosyl-galactosides, raffinose and loliose, are affected by drought stress in perennial ryegrass. Plant Physiol. 2003, 132, 2218-2229. [CrossRef] [PubMed]

51. Yáñez, A.; Tapia, G.; Guerra, F.; Del Pozo, A. Stem carbohydrate dynamics and expression of genes involved in fructan accumulation and remobilization during grain growth in wheat (Triticum aestivum L.) genotypes with contrasting tolerance to water stress. PLOS ONE 2017, 12, e0177667.

52. Yokota, H.; Iehisa, J.C.M.; Shimosaka, E.; Takumi, S. Line differences in Cor/Lea and fructan biosynthesis-related gene transcript accumulation are related to distinct freezing tolerance levels in synthetic wheat hexaploids. J. Plant Physiol. 2015, 176, 78-88. [CrossRef] [PubMed]

53. Abeynayake, S.W.; Etzerodt, T.P.; Jonaviena, K.; Byrne, S.; Asp, T.; Boelt, B. Fructan metabolism and changes in fructan composition during cold acclimation in perennial ryegrass. Front. Plant Sci. 2015, 6, 329. [CrossRef] [PubMed]

54. Suárez-González, E.M.; López, M.G.; Délano-Frier, J.P.; Gómez-Leyva, J.F. Expression of the 1-SST and 1-FFT genes and consequent fructan accumulation in Agave tequilana and A. inaequidens is differentially induced by diverse (a)biotic-stress related elicitors. J. Plant Physiol. 2014, 171, 359-372.

55. Rudd, J.J.; Kanyuka, K.; Hassani-Pak, K.; Derbyshire, M.; Andongabo, A.; Devonshire, J.; Lysenko, A.; Saqi, M.; Desai, N.M.; Powers, S.J.; et al. Transcriptome and Metabolite Profiling of the Infection Cycle of Zymoseptoria tritici on Wheat Reveals a Biphasic Interaction with Plant Immunity Involving Differential Pathogen Chromosomal Contributions and a Variation on the Hemibiotrophic Lifest. Plant Physiol. 2015, 167, 1158-1185. [CrossRef] [PubMed]

56. Gaudet, D.A.; Laroche, A.; Yoshida, M. Low temperature-wheat-fungal interactions: A carbohydrate connection. Physiol. Plant. 1999, 106, 437-444. [CrossRef]

57. Wang, F.; Feng, G.; Chen, K. Burdock fructooligosaccharide induces resistance to tobacco mosaic virus in tobacco seedlings. Physiol. Mol. Plant Pathol. 2009, 74, 34-40. [CrossRef]

58. Zhang, P.Y.; Wang, J.C.; Liu, S.H.; Chen, K.S. A novel burdock fructooligosaccharide induces changes in the production of salicylates, activates defence enzymes and induces systemic acquired resistance to Colletotrichum orbiculare in cucumber seedlings. J. Phytopathol. 2009, 157, 201-207. [CrossRef]

59. Williamson, B.; Tudzynski, B.; Tudzynski, P.; van Kan, J.A.L. Botrytis cinerea: The cause of grey mould disease. Mol. Plant Pathol. 2007, 8, 561-580. [CrossRef] [PubMed]

60. De Cremer, K.; Mathys, J.; Vos, C.; Froenicke, L.; Michelmore, R.W.; Cammue, B.P.A.; De Coninck, B. RNAseq-based transcriptome analysis of Lactuca sativa infected by the fungal necrotroph Botrytis cinerea. Plant Cell Environ. 2013, 36, 1992-2007. [PubMed]

61. Daudi, A.; Cheng, Z.; O’Brien, J.A.; Mammarella, N.; Khan, S.; Ausubel, F.M.; Bolwell, G.P. The Apoplastic Oxidative Burst Peroxidase in Arabidopsis Is a Major Component of Pattern-Triggered Immunity. Plant Cell 2012, 24, 275-287. [CrossRef] [PubMed]

62. Sisler, E.C.; Dupille, E.; Serek, M. Effect of 1-methylcyclopropene and methylenecyclopropane on ethylene binding and ethylene action on cut carnations. J. Plant Growth Regul. 1996, 18, 79-86. [CrossRef]

63. Even-Chen, Z.; Mattoo, A.K.; Goren, R. Inhibition of ethylene biosynthesis by aminoethoxyvinylglycine and by polyamines shunts label from 3,4-[C]methionine into spermidine in aged orange peel discs. Plant Physiol. 1982, 69, 385-388. [CrossRef] [PubMed]

64. Sun, F.; Zhang, P.; Guo, M.; Yu, W.; Chen, K. Burdock fructooligosaccharide induces fungal resistance in postharvest Kyoho grapes by activating the salicylic acid-dependent pathway and inhibiting browning. Food Chem. 2013, 138, 539-546. [CrossRef] [PubMed]

65. Arnault, I.; Lombarkia, N.; Joy-Ondet, S.; Romet, L.; Brahim, I.; Meradi, R.; Nasri, A.; Auger, J.; Derridj, S. Foliar application of microdoses of sucrose to reduce codling moth Cydia pomonella L. (Lepidoptera: Tortricidae) damage to apple trees. Pest. Manag. Sci. 2016, 72, 1901-1909. [CrossRef] [PubMed] 
66. Lee, O.; Sugiyama, N. Changes in carbohydrate composition in lettuce flower stalks during development. J. Hortic. Sci. Biotechnol. 2006, 81, 928-932. [CrossRef]

67. Vogt, L.M.; Meyer, D.; Pullens, G.; Faas, M.M.; Venema, K.; Ramasamy, U.; Schols, H.A.; de Vos, P. Toll-Like Receptor 2 Activation by $\beta 2 \rightarrow$ 1-Fructans Protects Barrier Function of T84 Human Intestinal Epithelial Cells in a Chain Length-Dependent Manner. J. Nutr. 2014, 2, 1002-1008. [CrossRef] [PubMed]

68. Franco-Robles, E.; López, M.G. Implication of fructans in health: Immunomodulatory and antioxidant mechanisms. Sci. World J. 2015, 2015, 289267. [CrossRef] [PubMed]

69. Versluys, M.; Tarkowski, Ł.P.; Van den Ende, W. Fructans As DAMPs or MAMPs: Evolutionary Prospects, Cross-Tolerance, and Multistress Resistance Potential. Front. Plant Sci. 2017, 7, 2061. [CrossRef] [PubMed]

70. Vereyken, I.J.; Chupin, V.; Demel, R.A.; Smeekens, S.C.M.; de Kruijff, B. Fructans insert between the headgroups of phospholipids. Biochim. Biophys. Acta Biomembr. 2001, 1510, 307-320. [CrossRef]

71. Aziz, A.; Heyraud, A.; Lambert, B. Oligogalacturonide signal transduction, induction of defense-related responses and protection of grapevine against Botrytis Cinerea. Planta 2004, 218, 767-774. [CrossRef] [PubMed]

72. Ferrari, S.; Galletti, R.; Denoux, C.; de Lorenzo, G.; Ausubel, F.M.; Dewdney, J. Resistance to Botrytis cinerea Induced in Arabidopsis by Elicitors Is Independent of Salicylic Acid, Ethylene, or Jasmonate Signaling But Requires PHYTOALEXIN DEFICIENT3. Plant Physiol. 2007, 144, 367-379. [CrossRef] [PubMed]

73. Lamb, C.; Dixon, R. The oxidative burst in plant disease resistance. Annu. Rev. Plant Physiol. Plant Mol. Biol. 1997, 48, 251-275. [CrossRef] [PubMed]

74. Camejo, D.; Guzmán-Cedeño, Á.; Moreno, A. Reactive oxygen species, essential molecules, during plant-pathogen interactions. Plant Physiol. Biochem. 2016, 103, 10-23. [CrossRef] [PubMed]

75. Ben Rejeb, K.; Vos, L.D.; Le Disquet, I.; Leprince, A.S.; Bordenave, M.; Maldiney, R.; Jdey, A.; Abdelly, C.; Savouré, A. Hydrogen peroxide produced by NADPH oxidases increases proline accumulation during salt or mannitol stress in Arabidopsis thaliana. New Phytol. 2015, 208, 1138-1148. [CrossRef] [PubMed]

76. Bellincampi, D.; Dipierro, N.; Salvi, G.; Cervone, F.; de Lorenzo, G. Extracellular H(2)O(2) induced by oligogalacturonides is not involved in the inhibition of the auxin-regulated rolB gene expression in tobacco leaf explants. Plant Physiol. 2000, 122, 1379-1385. [CrossRef] [PubMed]

77. Torres, M.A.; Jones, J.D.G.; Dangl, J.L. Reactive oxygen species signaling in response to pathogens. Plant Physiol. 2006, 141, 373-378. [CrossRef] [PubMed]

78. Galletti, R.; Denoux, C.; Gambetta, S.; Dewdney, J.; Ausubel, F.M.; de Lorenzo, G.; Ferrari, S. The AtrbohD-Mediated Oxidative Burst Elicited by Oligogalacturonides in Arabidopsis Is Dispensable for the Activation of Defense Responses Effective against Botrytis cinerea. Plant Physiol. 2008, 148, 1695-1706. [CrossRef] [PubMed]

79. Małolepsza, U.; Urbanek, H. O-hydroxyethylorutin-mediated enhancement of tomato resistance to Botrytis cinerea depends on a burst of reactive oxygen species. J. Phytopathol. 2002, 150, 616-624. [CrossRef]

80. Unger, C.; Kleta, S.; Jandl, G.; Tiedemann, A.V. Suppression of the defence-related oxidative burst in bean leaf tissue and bean suspension cells by the necrotrophic pathogen Botrytis cinerea. J. Phytopathol. 2005, 153, 15-26. [CrossRef]

81. Lu, X.; Jiang, W.; Zhang, L.; Zhang, F.; Zhang, F.; Shen, Q.; Wang, G.; Tang, K. AaERF1 Positively Regulates the Resistance to Botrytis cinerea in Artemisia annua. PLoS ONE 2013, 8, e57657. [CrossRef] [PubMed]

82. Diaz, J.; ten Have, A.; van Kan, J.A.L. The Role of Ethylene and Wound Signaling in Resistance of Tomato to Botrytis cinerea. Plant Physiol. 2002, 129, 1341-1351. [CrossRef] [PubMed]

83. García, T.; Gutiérrez, J.; Veloso, J.; Gago-Fuentes, R.; Díaz, J. Wounding induces local resistance but systemic susceptibility to Botrytis cinerea in pepper plants. J. Plant Physiol. 2015, 176, 202-209. [CrossRef] [PubMed]

84. Ingle, R.A.; Stoker, C.; Stone, W.; Adams, N.; Smith, R.; Grant, M.; Carré, I.; Roden, L.C.; Denby, K.J. Jasmonate signalling drives time-of-day differences in susceptibility of Arabidopsis to the fungal pathogen Botrytis cinerea. Plant J. 2015, 84, 937-948. [CrossRef] [PubMed]

85. Hu, Z.; Shao, S.; Zheng, C.; Sun, Z.; Shi, J.; Yu, J.; Qi, Z.; Shi, K. Induction of systemic resistance in tomato against Botrytis cinerea by N-decanoyl-homoserine lactone via jasmonic acid signaling. Planta 2018, 247, 1217-1227. [CrossRef] [PubMed]

86. Ceusters, J.; Van de Poel, B. Ethylene exerts species-specific and age-dependent control of photosynthesis. Plant Physiol. 2018, 176, 2601-2612. [CrossRef] [PubMed] 
87. Pierik, R.; Tholen, D.; Poorter, H.; Visser, E.J.W.; Voesenek, L.A.C.J. The Janus face of ethylene: Growth inhibition and stimulation. Trends Plant Sci. 2006, 11, 176-183. [CrossRef] [PubMed]

88. Gómez-Ariza, J.; Campo, S.; Rufat, M.; Estopà, M.; Messeguer, J.; San Segundo, B.; Coca, M. Sucrose-mediated priming of plant defense responses and broad-spectrum disease resistance by overexpression of the maize pathogenesis-related PRms protein in rice plants. Mol. Plant Microbe Interact. 2007, 20, 832-842. [CrossRef] [PubMed]

89. Tauzin, A.S.; Giardina, T. Sucrose and invertases, a part of the plant defense response to the biotic stresses. Front. Plant Sci. 2014, 5, 293. [CrossRef] [PubMed]

90. Siddappaji, M.H.; Scholes, D.R.; Krishnankutty, S.M.; Calla, B.; Clough, S.J.; Zielinski, R.E.; Paige, K.N. The role of invertases in plant compensatory responses to simulated herbivory. BMC Plant Biol. 2015, 15, 278. [CrossRef] [PubMed]

91. Caretto, S.; Linsalata, V.; Colella, G.; Mita, G.; Lattanzio, V. Carbon fluxes between primary metabolism and phenolic pathway in plant tissues under stress. Int. J. Mol. Sci. 2015, 16, 26378-26394. [CrossRef] [PubMed]

92. Cho, J.-I.; Lee, S.-K.; Ko, S.; Kim, H.-K.; Jun, S.-H.; Lee, Y.-H.; Bhoo, S.H.; Lee, K.-W.; An, G.; Hahn, T.-R.; et al. Molecular cloning and expression analysis of the cell-wall invertase gene family in rice (Oryza sativa L.). Plant Cell Rep. 2005, 24, 225-236. [CrossRef] [PubMed]

93. Berger, S.; Papadopoulos, M.; Schreiber, U.; Kaiser, W.; Roitsch, T. Complex regulation of gene expression, photosynthesis and sugar levels by pathogen infection in tomato. Physiol. Plant. 2004, 122, 419-428. [CrossRef]

94. Veillet, F.; Gaillard, C.; Coutos-Thévenot, P.; La Camera, S. Targeting the AtCWIN1 Gene to Explore the Role of Invertases in Sucrose Transport in Roots and during Botrytis cinerea Infection. Front. Plant Sci. 2016, 7, 1899. [CrossRef] [PubMed]

95. Roitsch, T.; Balibrea, M.E.; Hofmann, M.; Proels, R.; Sinha, A.K. Extracellular invertase: Key metabolic enzyme and PR protein. J. Exp. Bot. 2003, 54, 513-524. [CrossRef] [PubMed]

96. Linden, J.C.; Ehneß, R.; Roitsch, T. Ethylene regulation of apoplastic invertase expression in autotrophic cells of Chenopodium rubrum. Plant Growth Regul. 1996, 19, 219-222. [CrossRef]

97. Lukaszuk, E.; Rys, M.; Możdżeń, K.; Stawoska, I.; Skoczowski, A.; Ciereszko, I. Photosynthesis and sucrose metabolism in leaves of Arabidopsis thaliana aos, ein4 and rcd1 mutants as affected by wounding. Acta Physiol. Plant. 2017, 39, 17. [CrossRef]

98. Kasmi, F.; El Horvath, D.; Lahaye, T. Microbial effectors and the role of water and sugar in the infection battle ground. Curr. Opin. Plant Biol. 2018, 44, 98-107. [CrossRef] [PubMed]

99. Siemens, J.; González, M.C.; Wolf, S.; Hofmann, C.; Greiner, S.; Du, Y.; Rausch, T.; Roitsch, T.; Ludwig-Müller, J. Extracellular invertase is involved in the regulation of clubroot disease in Arabidopsis thaliana. Mol. Plant Pathol. 2011, 12, 247-262. [CrossRef] [PubMed]

100. Michaeli, S.; Fromm, H. Closing the loop on the GABA shunt in plants: Are GABA metabolism and signaling entwined? Front. Plant Sci. 2015, 6, 419. [CrossRef] [PubMed]

101. Seifi, H.S.; Curvers, K.; de Vleesschauwer, D.; Delaere, I.; Aziz, A.; Höfte, M. Concurrent overactivation of the cytosolic glutamine synthetase and the GABA shunt in the ABA-deficient sitiens mutant of tomato leads to resistance against Botrytis cinerea. New Phytol. 2013, 199, 490-504. [CrossRef] [PubMed]

102. Kathiresan, A.; Tung, P.; Chinnappa, C.; Reid, D. $\gamma$-Aminobutyric Acid Stimulates Ethylene Biosynthesis in Sunflower. Plant Physiol. 1997, 115, 129-135. [CrossRef] [PubMed]

103. Fabro, G.; Kovács, I.; Pavet, V.; Szabados, L.; Alvarez, M.E. Proline Accumulation and AtP5CS2 Gene Activation Are Induced by Plant-Pathogen Incompatible Interactions in Arabidopsis. Mol. Plant. Microbe Interact. 2004, 17, 343-350. [CrossRef] [PubMed]

104. Cecchini, N.M.; Monteoliva, M.I.; Alvarez, M.E. Proline Dehydrogenase Contributes to Pathogen Defense in Arabidopsis. Plant Physiol. 2011, 155, 1947-1959. [CrossRef] [PubMed]

105. Juszczak, I.; Baier, M. Quantification of Superoxide and Hydrogen peroxide in leaves. In Plant Cold Acclimation: Methods and Protocols; Springer Science+Business: New York, NY, USA, 2014; pp. 217-224.

106. Shiomi, N.; Onodera, S.; Chatterton, N.J.; Harrison, P.A. Separation of fructooligosaccharide isomers by anion-exchange chromatography. Agric. Biol. Chem. 1991, 55, 1427-1428.

107. Hao, L.; Chen, L.; Zhong, N.; Chen, K.; Li, G. Separation, Purification and Structure of Burdock Oligosaccharide. Chem. J. Chin. Univ. 2005, 26, 1242-1247. 
108. Le Roy, K.; Lammens, W.; Verhaest, M.; De Coninck, B.; Rabijns, A.; Van Laere, A.; Van den Ende, W. Unraveling the Difference between Invertases and Fructan Exohydrolases: A Single Amino Acid (Asp-239) Substitution Transforms Arabidopsis Cell Wall Invertase1 into a Fructan 1-Exohydrolase. Plant Physiol. 2007, 145, 616-625. [CrossRef] [PubMed]

109. De Coninck, B.; Le Roy, K.; Francis, I.; Clerens, S.; Vergauwen, R.; Halliday, A.M.; Smith, S.M.; Van Laere, A.; Van den Ende, W. Arabidopsis AtcwINV3 and 6 are not invertases but are fructan exohydrolases (FEHs) with different substrate specificities. Plant Cell Environ. 2005, 28, 432-443. [CrossRef]

(C) 2019 by the authors. Licensee MDPI, Basel, Switzerland. This article is an open access article distributed under the terms and conditions of the Creative Commons Attribution (CC BY) license (http:/ / creativecommons.org/licenses/by/4.0/). 